\title{
Drivers of decoupling and recoupling of crop and livestock systems at farm and territorial scales
}

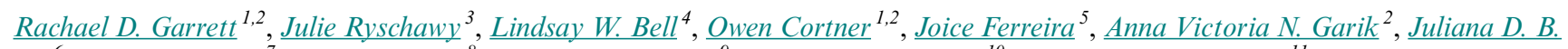

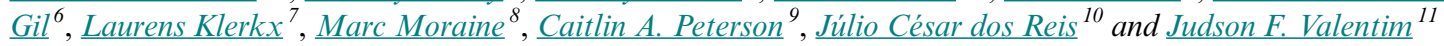

\begin{abstract}
Crop and livestock production have become spatially decoupled in existing commercial agricultural regimes throughout the world. These segregated high input production systems contribute to some of the world's most pressing sustainability challenges, including climate change, nutrient imbalances, water pollution, biodiversity decline, and increasingly precarious rural livelihoods. There is substantial evidence that by closing the loop in nutrient and energy cycles, recoupling crop and livestock systems at farm and territorial scales can help reduce the environmental externalities associated with conventional commercial farming without declines in profitability or yields. Yet such "integrated" crop and livestock systems remain rare as a proportion of global agricultural area. Based on an interdisciplinary workshop and additional literature review, we provide a comprehensive historical and international perspective on why integrated crop and livestock systems have declined in most regions and what conditions have fostered their persistence and reemergence in others. We also identify levers for encouraging the reemergence of integrated crop and livestock systems worldwide. We conclude that a major disruption of the current regime would be needed to foster crop-livestock reintegration, including a redesign of research programs, credit systems, payments for ecosystem services, insurance programs, and food safety regulations to focus on whole farm outcomes and the creation of a circular economy. An expansion of the number of integrated crop and livestock systems field trials and demonstrations and efforts to brand integrated crop and livestock systems as a form of sustainable agriculture through the development of eco-labels could also improve adoption, but would likely be unsuccessful at encouraging wide-scale change without a more radical transformation of the research and policy landscape.
\end{abstract}

Key Words: innovation; integrated crop livestock systems; mixed farming systems; socio-technical transitions; sustainable agriculture; technology adoption

\section{INTRODUCTION}

Crop and livestock production is essential to human well-being, yet contributes to numerous global sustainability challenges. It is the largest land and fresh water user on the planet, largest source of GHG emissions and water pollution in many countries, and a major driver of global biodiversity loss (Vitousek et al. 1997, Tilman et al. 2002, Foley et al. 2005, Henders et al. 2015). Many of the undesirable social and ecological outcomes of agriculture can be traced to the decoupling of global crop and livestock systems and increased adoption of specialized, continuous cropping or livestock operations (Naylor et al. 2005). The origins of these systems can, in turn, be traced to shifts in the political economy of global food systems, including an orientation toward capitalist logic, including surplus production, liberalization of trade, technological supremacy, and financialization (McMichael 2009).

Specialized systems are characterized on the cropping side by frequent tillage and synthetic input use to reduce pest and weed pressure and manage nutrient availability, leading to erosion, pollution, and rising costs of production, and on the livestock side by waste accumulation, leading to high pollution and greenhouse gas emissions (Pimentel et al. 1995, Tilman et al. 2001, Pimentel 2005, Chadwick et al. 2011). This specialization of agricultural management tends to make farmers more exposed to weather and market variability risks and creates an ecological and technological treadmill of production, such that each solution only creates additional challenges (Ward 1993). This treadmill, though seemingly paradoxical from a farmer perspective, has clear benefits for multinational agribusiness firms by creating demand for their goods and services.

Innovative solutions are needed to tackle these broad ranging challenges at their root cause, i.e., considering sustainability and resilience throughout the conception, implementation, and management of food systems (and associated landscapes), instead of focusing on economic and production outcomes (Therond et al. 2017). Systems that increase the diversity of agricultural production activities in time and space have been proposed as a mechanism to improve sustainability and resilience. Examples include permaculture, diversified cropping systems, and integrated crop, livestock, and forestry systems (agricultural systems that integrate crops, livestock, and/or trees on the same area, for example, via intercropping or rotations). Here we focus on integrated crop and livestock systems (ICLS), systems that specifically recouple the crop and livestock dimensions of farming, as a potential solution. Various case studies throughout the world have shown that ICLS in commercial agricultural

\footnotetext{
${ }^{1}$ Environmental Policy Group, Departments of Environmental Systems Science and Humanities, Social, and Political Sciences, ETH Zürich, Zürich, Switzerland, ${ }^{2}$ Department of Earth and Environment, Boston University, MA, USA, ${ }^{3}$ AGIR, Université de Toulouse, INPT, INRAE, France, ${ }^{4}$ CSIRO Agriculture and Food, Toowoomba Qld, Australia, ${ }^{5}$ Embrapa Amazônia Oriental, Belém, Brazil, ${ }^{6}$ Plant Production Systems, Wageningen University, Wageningen, The Netherlands, ${ }^{7}$ Knowledge, Technology and Innovation Group, Wageningen University, The Netherlands, ${ }^{8}$ UMR 0951 INNOVATION, INRAE, CIRAD, Montpellier SupAgro, Montpellier, France, ${ }^{9}$ Department of Plant Sciences, University of California, Davis, CA, USA, ${ }^{10}$ Embrapa Agrossilvipastoril, Sinop, Mato Grosso, Brazil, ${ }^{11}$ Agroforestry Research Center of Acre, Embrapa Acre, Rio Branco, Acre, Brazil
} 
landscapes are associated with lower environmental externalities than conventional farming, without declines in profitability or yields (Lemaire et al. 2013, Franzluebbers et al. 2014, Garrett et al. 2017a, Ryschawy et al. 2017, dos Reis et al. 2019). ICLS may also enhance ecosystem services both on- and off-farm, for example, erosion control and nutrient cycling, and increase farm productivity as a function of all inputs, i.e., total factor productivity (Coomes et al. 2019).

Despite substantial research on their environmental and economic performance, surprisingly little is known about the prevalence and trajectories of ICLS globally. Why have ICLS been retired in some regions, and persisted or reemerged in others (Garrett et al. 2017a)? Why have specialized (nonintegrated) systems come to dominate most commercial agricultural production despite their numerous negative impacts? Past studies have examined the importance of mixed crop and livestock systems in smallholder subsistence production, largely in subSaharan Africa and Asia (Thornton et al. 2002, Thornton and Herrero 2015). However, the drivers for decoupling and reintegration of crop and livestock in commercial systems, e.g., farms that primarily sell, rather than consume their own production, particularly in North and South America, Europe, and Oceania, remain poorly understood (Garrett et al. 2017a).

Given the complex distal and multilevel interactions influencing agricultural systems (Hull and Liu 2018, Garrett and Rueda 2019), an international and historical perspective on the drivers of crop and livestock decoupling and conditions for their persistence and reemergence is urgently needed. Based on a workshop involving international ICLS scientists and practitioners we analyzed secondary data and case studies to draw general conclusions on the factors influencing ICLS prevalence and trajectories within commercial agricultural systems. We ask the following: (1) What are current trends in ICLS adoption or retirement? (2) What are the causes of ICLS persistence, adoption, or retirement? (3) What policy levers could contribute to greater adoption of ICLS? We use a multilevel perspective of system innovations, i.e., a means of explaining how technological transitions come about in a given multilevel context, (Geels 2011) to understand current ICLS prevalence and trajectories.

\section{TYPES OF ICLS}

Understanding variation in crop and livestock system types across gradients of integration is useful to clarify the expected benefits, trade-offs, and barriers to adoption. Previous work has classified integrated systems according to their reliance on inputs, capital and labor (Schiere et al. 2002), space, time, ownership, and management (Bell and Moore 2012), and the level of interactions between crops, livestock, and animals (Moraine et al. 2017). Building on these typologies, we define systems with the lowest level of integration as segregated high input agriculture, or segregated-HIA (Fig. 1), where crop and livestock units interact primarily through the market. Segregated HIA crop systems often produce very high yields, but rely on high levels of synthetic fertilizer and pesticides. Segregated HIA livestock systems also rely heavily on off-farm feed sources and aggregate high densities of livestock on a small land area, leading to the production of manure volumes that tend to exceed the assimilative capacity of the land that they occupy.
Fig. 1. Types of integrated systems according to the level of integration between livestock and crops and the levels of inputs used. Crop systems are indicated by $(\mathrm{C})$, while livestock systems are disaggregated into animals (A) and pastures $(\mathrm{P})$. The size of the arrows represents differences in volumes of inputs (e.g., feed, fertilizer, pesticides, etc.), outputs (e.g., food, biomass, or nutrients with commercial value), and losses (nutrient losses, greenhouse gases emissions). The size of the bubbles is meant to represent productivity of the crop, pasture, and animal components relative to inputs and outputs. In segregated-HIA (high input agriculture) and semi-ICLS (integrated crop and livestock systems) animals are present, but there is no pasture component (they are fed harvested forages, crops, and crop residues). Traditional-ICLS involve grazing on pastures, but often have low levels of external inputs and/or poor management, leading to an underutilization of potential synergies between systems. New-ICLS (on the right) differ from traditional-ICLS, segregated-HIA, and semi-ICLS (on the left) in that they seek to maintain high outputs while reducing external inputs and increasing input efficiency through synergies between crop and livestock systems, thereby maintaining or increasing economic competitiveness. Territorial ICLS occur at the landscape level, i.e., through local exchanges occurring between neighboring farms (lower right side). Given greater synergies in space and time between functional agrobiodiversity (crops, pastures, and animals), sustainability and resilience is expected to increase as one moves from segregated-HIA practices to semi-ICL to territorial-ICL to new-ICL systems.

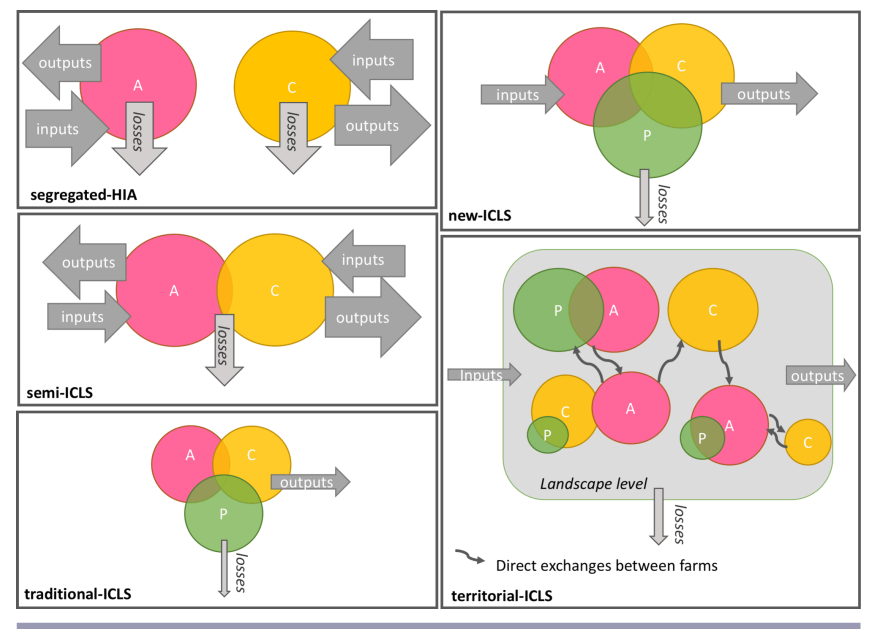

At the other end of the integration spectrum, crops and livestock can be highly coupled through crop-pasture rotation and in situ animal grazing, which increases nutrient availability for crops and can improve soil structure, if kept at low to moderate grazing intensities (Schiere et al. 2002, Garrett et al. 2017a). We refer to all of these systems as ICLS, distinguishing between traditional-, new-, and territorial-ICLS. Traditional-ICLS, which have been around for centuries, have no or very low external resource inputs. They rely almost entirely on on-farm resources to manage nutrient supply and weed pressure, rather than external inputs of fertilizers and chemicals. New-ICLS are a form of "retro-innovation" 
(Stuiver 2006, Sixt et al. 2018), combining traditional-ICLS practices with modern advances to maximize the economic and ecological benefits linked to greater levels of integration and support agricultural regime change. Territorial-ICLS are direct exchanges of crop and livestock products among farmers. The system of organization linking these farmers often occurs at the landscape level, e.g., a watershed, community, island, or complementary plain and mountain areas. Somewhere in the middle of segregated-HIA and ICLS are semi-ICLS, systems that have only minimal levels of integration. Crops grown on the farm are harvested and may be used to supplement livestock on another part of the farm, rather than directly grazed, and/or excess manure is collected and distributed as fertilizer, rather than directly deposited by animals. The logic of these systems is (i) to keep costs down by maintaining economies of scale via specialized land use and producing one's own feed supply for livestock, and (ii) like all integrated systems, to diversify income streams. The farms participating in territorial-ICLS systems may be semi-ICLS or segregated-HIA systems (Moraine et al. 2017). A common conclusion of several existing farm system typologies (Schiere et al. 2002, Bell and Moore 2012, Moraine et al. 2017) is that more integrated farms are likely to be more sustainable and resilient because of synergies in space and time between functional agrobiodiversity, i.e., crops, pastures, and animals (Stuiver 2006, Sixt et al. 2018; Fig. 1).

\section{METHODS}

We used a multilevel perspective (Geels 2011) to understand the prevalence and trajectory of different types of ICLS within countries, following Gaitán-Cremaschi et al. (2019) who used it as a food system diagnostic and classification tool. This perspective focuses on three levels to explain how socio-technical transitions occur and how social, technological, and institutional aspects coevolve: (i) landscapes: the external factors influencing the whole agricultural system, such as socio-technical trends (e.g., globalization) or climate change (e.g., reductions or changes in the distribution of rainfall) that may put pressure on agricultural regimes and create windows of opportunity for niches (Wigboldus et al. 2016), (ii) agricultural regimes: the dominant modes of production, sourcing, value accumulation, and consumption in agricultural supply chains, evolving product markets and market demands, the focus of the policy setting, and scientific and technological paradigms (McMichael 2005, Gaitán-Cremaschi et al. 2019), and (iii) niches: networks in which novel systems are developed that propose an alternative to the current agricultural regime that may come both from deviant or change-oriented actors within the regime and from grassroots innovation movements (Tittonell et al. 2016). Using this perspective, we can assess to what extent ICLS may originate from within existing agricultural regimes or as niche systems outside existing regimes.

Data from agricultural censuses (outlined in Appendix 1) were synthesized to describe the status of ICLS in each region. The definitions used to identify ICLS farms in these censuses vary across countries and ICLS data were not available for all regions (Appendix 1). We excluded forestry from our analysis because of limited data and research on systems that also integrate trees.

A review of the existing literature and a consultative process with ICLS and agricultural innovation experts within each of the major focal regions were used to trace the reasons for the relative abundance and trajectory (decline, stability, or resurgence) of ICLS across regions. Identification of factors influencing ICLS adoption and retirement began with a two-day workshop with 18 international ICLS scientists and practitioners and agricultural innovation experts from Australia, Brazil, Europe, and the United States as part of a National Science Foundation "Science, Engineering, and Education for Sustainability" grant (\#1415352). The meeting took place in August 2017 in Belém, Brazil, through a partnership between Boston University and Embrapa (more details included in Appendix 2). This workshop was supplemented with an extensive literature review of both the limited ICLS literature and broader research on farm structural changes, farm diversity, and sustainable agriculture. More details on our qualitative characterization of these conditions can be found in Appendix 3.

\section{EXPLAINING ICLS ABUNDANCE AND TRAJECTORIES IN COMMERCIAL AGRICULTURE}

Status of ICLS in regions where data are available

ICLS were once highly abundant in North America, but have been decreasing as a proportion of both agricultural area and farms since at least 1970 (Fig. 2a-b). Most farms are now best described as segregated-HIA. From 1900 to 2002, U.S. farms went from producing (on average) five agricultural commodities per farm to just a single commodity per farm (Dimitri et al. 2005). Nevertheless, ICLS remain moderately abundant in North America, compared to other commercial production regions (Fig. 2c). Canada has one of the highest levels of mixed crop and livestock production in terms of both area $(43 \%)$ and farms $(29 \%)$ across the commercial production regions for which there are data. In the U.S., traditional-ICLS have been maintained in Amish country and various forms of new-ICLS have been documented at low levels in New England, the Great Plains, and the High Plains, including grazing of cover crops and crop stubble, sometimes in association with permaculture, organic, and biodynamic farms (Warren 1994, Cunfer 2004, Allen et al. 2005, Lovell et al. 2010, Faust et al. 2018).

Levels of integration did not change as precipitously in Western Europe after 1980 because they were already quite low (Fig. 2b). Traditional-ICLS in Europe have been mostly maintained in lessfavored areas (regions with inferior market access or soil and climatic conditions, such as mountainous regions), particularly in association with dairy production (Entz et al. 2005, Veysset et al. 2005). Segregated-HIA have become the dominant form of agriculture in most other regions. Several countries in Central, e.g., Poland, Slovakia, and Baltic Europe, e.g., Lithuania, Latvia, show a slightly different story for the years that data are available. In Poland and Slovakia, ICLS levels remained fairly steady between 2003 and 2013, but higher than Western Europe, at around $20 \%$ of the farms. In Lithuania and Latvia, ICLS levels declined quickly after 2003, but are still more than double most Western European countries.

In contrast to other regions, Australia, Brazil, Uruguay, and most recently New Zealand, have all experienced a combination of resurgence and persistence in ICLS. In Australia, farms maintaining a mix of crops and livestock that are integrated to varying degrees remain common, covering roughly $50 \%$ of the agricultural area (roughly 46 million hectares), excluding the 
Fig. 2. Integrated crop and livestock systems (ICLS) as percentage of agricultural area or farms by country. NZ $=$ New Zealand, UK = United Kingdom. US= United States. Countries for which there at least 10 years of data for ICLS area were included only in Figure $2 a$ and not repeated in Figure $2 b$ even if they also contained data on farm numbers. In Figure 2c "the latest available year" is as follows: 2002 for Argentina, 2006 for Brazil, 2010 for Iceland, Montenegro, and Switzerland, 2011 for Uruguay, 2012 for US and NZ, 2015 for Japan and Saudia Arabia, 2016 for Canada, 2017 for Australia, and 2013 for all other countries. See Table A.1 for ICLS definitions and calculations and years of data availability by country.

(a) ICLS as a Percent of Area by Country

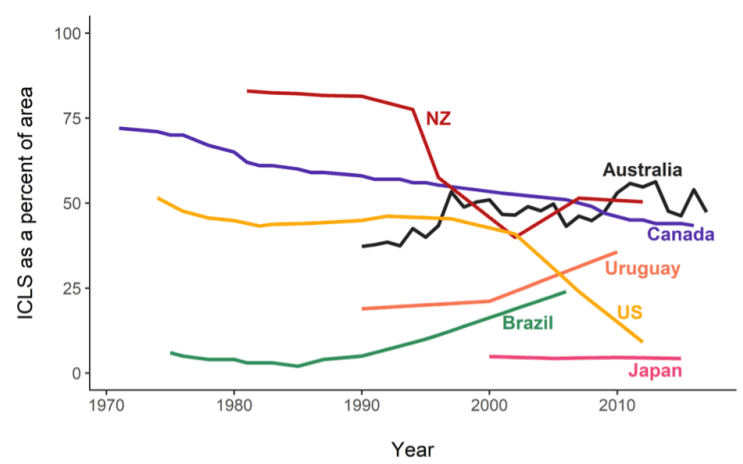

(b) ICLS as a Percent of Farms by Country

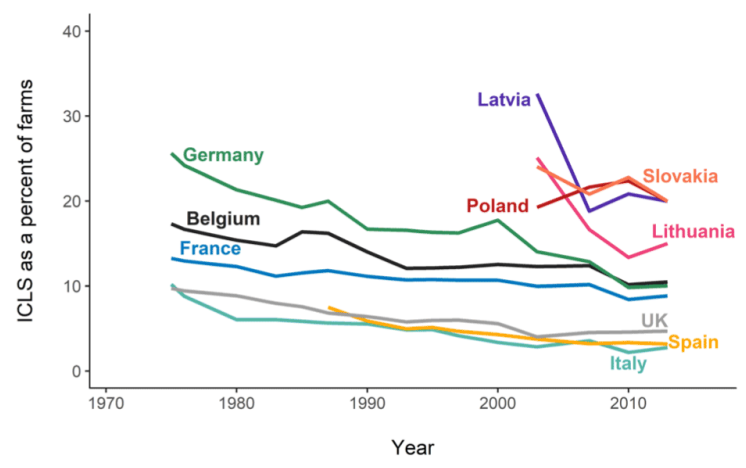

(c) ICLS as a Percent of Area or Farms (Latest Available Year)

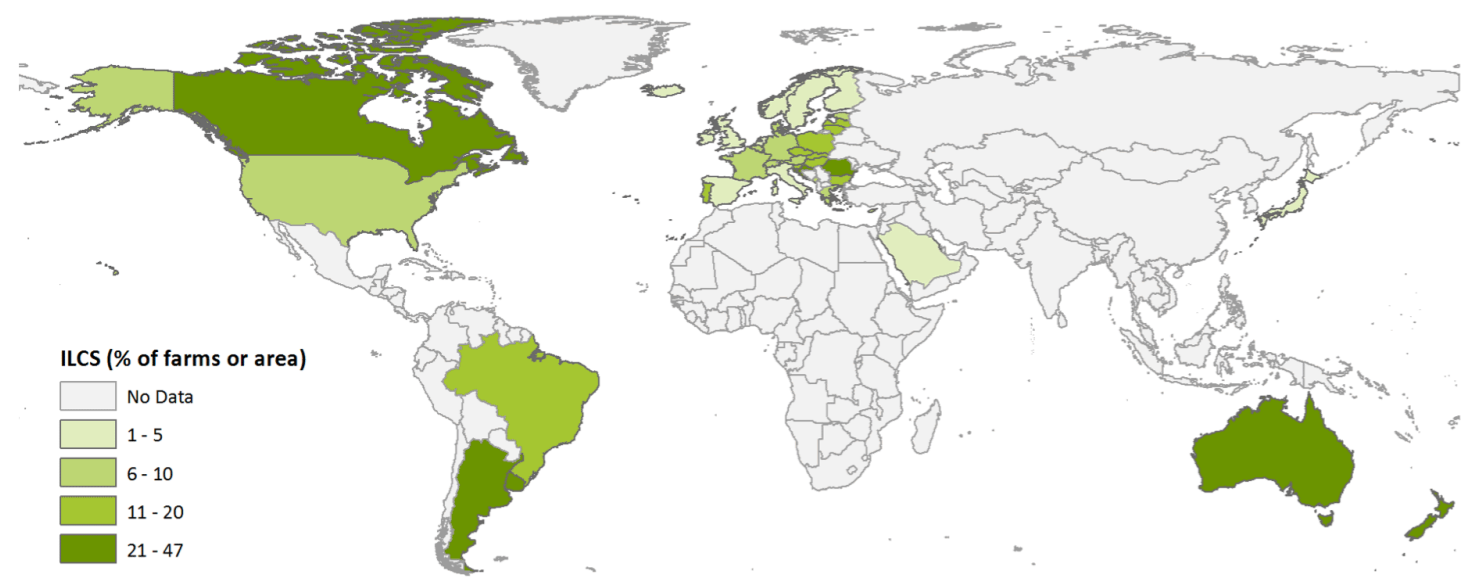

extensive pastoral grazing regions of the interior (Fig. 2a). These farms include both semi- and new-ICLS with trends of increasing intensity and specialization to cropping (Garrett et al. 2017a), but still $40 \%$ of the cropped area on these farms involve new-ICLS practices. In New Zealand, there are high levels of integration of sheep and beef cattle in grain and viticulture cropping regions. As of $2012,50 \%$ of grain cropping area and $44 \%$ of grain farms pursued integrated grain-beef or grain-sheep production (Statistics New Zealand 2012). Yet, levels of integration remain low as a proportion of the total agricultural land area in New Zealand (only 126,000 hectares) because there are still $>25,000$ pastoral farms, comprising $>7$ million hectares that pursue specialized beef and/or sheep production in the hilly grasslands (Statistics New Zealand 2012). In Brazil, many smaller scale family farms have maintained traditional-ICLS, while new-ICLS is increasing on larger, commercial farms in the form of integrated grain-beef production (Balbino et al. 2011, Carvalho et al. 2014, Gil et al. 2015, Vicente 2016). Between 2005 and 2015, the area occupied by ICLS increased from 1.87 to 11.47 million hectares
(Embrapa 2016). In Uruguay, ICLS remains common in all forms of agriculture, including rice, beef cattle, and dairy cattle production, totaling 4.8 million hectares in 2011.

Very little data on ICLS was available for Asia or the Middle East. ICLS occupies $<10 \%$ of the agricultural area in Japan and $<1 \%$ of the farms in Saudi Arabia are ICLS (Fig. 2c). In Japan, because of the limited agricultural area, pastures have all but disappeared and most livestock are produced in confinement systems (Obara et al. 2010). In Saudi Arabia growing consumption of meat has made the country a growing livestock producer, but a lack of domestic water resources has led to a reliance on confinement systems and large imports of feed grains and live cattle for finishing (FAO 2017). Nevertheless, it is likely that ICLS remain common in small-scale commercial production systems throughout much of Asia (Devendra and Thomas 2002).

In summary, while once a "regime practice" (pre-1960), ICLS has become a niche in many commercial agricultural systems in much of the Global North, occupying $<10 \%$ of the agricultural area 
and number of farms in most of Northern, Central, and Western Europe, and the United States (Fig. 2c). In Brazil and Central and Baltic Europe roughly $15-25 \%$ of all farms are integrated, while $30 \%$ of all farms in Canada, $40-45 \%$ of nonpastoral farms in Australia and New Zealand, and $40-45 \%$ of all farms in Argentina and Uruguay are integrated.

These trends are summarized in Figure 3, which illustrates a general global timeline for traditional-ICLS retirement in most countries since at least 1960 , followed by reemergence of newICLS in some regions after 1990 from various starting points. In regions where traditional-ICLS were retired, new-ICLS has emerged from specialized-HIA or semi-ICLS systems, e.g., New Zealand, Australia. In other regions new-ICLS have evolved from the persistence of traditional-ICLS, e.g., Brazil. The regionspecific trajectories and transitions of ICLS adoption and retirement, and their associated causes, are discussed in more detail below.

Fig. 3. Trajectories of agricultural decoupling or integration of crop and livestock components. Historically, most traditional agricultural systems included both crops and livestock, i.e., traditional-ICLS (integrated crop and livestock systems). Since 1960, integrated systems declined in favor of specialized-HIA (high input agriculture) cropping or livestock production and semi-ICLS in commercial agricultural systems (a), though in some regions traditional-ICLS have persisted (b). New-ICLS have emerged as an alternative to traditional-ICLS, segregatedHIA, and semi-ICLS since 1990 (c). Yet, in most regions in the Global North they remain rare because of a lack of landscape pull factors (unsupportive global market, low remuneration of labor, habits of specialization, and policies leading to political and economic lock-in), despite some niche push factors (successful new-ICLS development, consumer awareness for environmental aspects, quality-labeled products) (d).

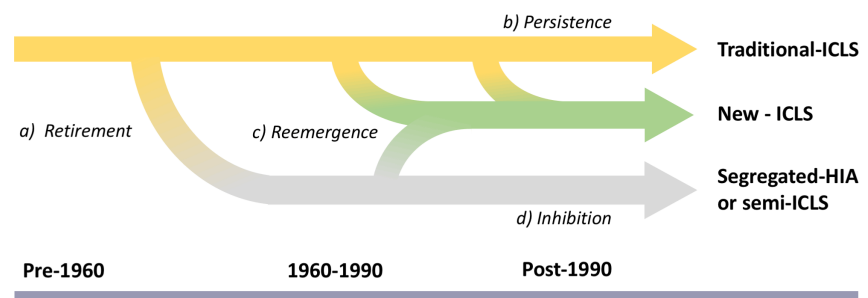

\section{Decline of ICLS because of large landscape changes}

The nearly universal decline of integrated crop-livestock systems in commercial agriculture is linked to several major structural landscape changes that occurred from 1960 to 2000. Major influences include globalization, industrial development, and the financialization of agriculture, which influenced the market integration of farms, relative input prices, and demands to compete on the world market (Barbieri et al. 2008, McMichael 2009, Ryschawy et al. 2013). Liberalization of trade throughout the latter half of the 20th century forced farms to compete globally, increasing incentives to specialize to enhance economies of scale and adopt technologies that reduced costs or increased yields (Entz et al. 2005, Vicente 2016). To gain global market share and protect farmers from international competition, many countries developed agricultural subsidy policies, such as the EU
Common Agricultural Policy in 1962 and the U.S. Farm Bill of 1933-1990 (Garrett et al. 2017b). These policies tended to focus on commodity crops, thereby increasing the profitability of specialized-HIA cropping versus more diversified cropping systems or ICLS (Garrett et al. 2017b). Given the increasing economic risks associated with the high costs and low diversity of these specialized production systems, some regions (including the U.S. with the Farm Bill) also developed insurance systems to protect farmers from climate and market fluctuations. Large-scale low-cost nitrogen fertilizer production further reduced farmers' reliance on livestock as a fertilizer source, allowing segregatedHIA cropland area to increase (Smil 1997). Similarly, the growing availability of labor-saving farm equipment and increasing costs of labor from demographic change and structural transformations in the economy (toward manufacturing and services) increased farmers' incentives to adopt more specialized agricultural systems that could employ mechanization to increase returns to labor.

Once a competitive advantage for an individual crop or livestock product was established, agglomeration economies, i.e., clusters of related agribusinesses, developed, leading to economies of scale and expansion of area devoted to individual crop or livestock products (Sulc and Tracy 2007, Garrett et al. 2013). In the context of globalization, multinational agribusiness companies assumed more power globally and in domestic politics (Kearney 2010). Such actors lobbied for continued market liberalization for a handful of crops that could be produced cheaply but increased in value via processing activities (McMichael 2009). A single product focus in agriculture was further cemented by the changes in the orientation of most agricultural research agencies and grant programs toward global competitiveness and biotechnology, rather than holistic farm outcomes, such as health, efficiency, and sustainability (Balbino et al. 2011, Bonaudo et al. 2014). Specialization was compounded by a more incremental technology transfer model of agricultural innovation for existing systems, rather than a reflexive, adaptive management approach to optimize farm and landscape ecosystems services (Moore 2011). All of these changes created path dependencies toward specialization and barriers to diversification.

Beginning in the 1990s, many countries reduced producer supports, e.g., subsidies, price supports, etc., in compliance with changes in world trade regulations (IMF 2017). Simultaneously, many countries, including the U.S., New Zealand, and the EU, established increasing environmental and soil conservation programs, e.g., U.S. Soil Conservation Service (later NRCS) in 1932; European Society for Soil Conservation in 1988; NZ Landcare Trust in 1996; NZ Soil Conservation and Rivers Control Act in 1941. Reductions in producer supports and increasing attention to environmental outcomes should have promoted greater input efficiency and diversification as alternative means to reduce costs, risk, and environmental impact (Bradshaw 2004, Garrett et al. 2017b). However, nonlabor input costs, e.g., fertilizers, pesticides, have remained relatively low across most countries as the environmental impacts of these products have not yet been captured by markets (Peyraud et al. 2014). Consequently, pressures to reduce economic risk and increase household income have tended to result in diversification of income via off-farm income opportunities, rather than on-farm production diversity and/or input reduction (Lobao and Meyer 2001, Bradshaw 2004). 


\section{Persistence of niches of traditional-ICLS within the dominant agricultural regime}

Traditional-ICLS persistence is often linked to cultural and economic factors (Table 1). Such systems could be a source of inspiration or "retro-innovation" to recreate connections between crops, grasslands, and animals within new-ICLS. As a potentially self-sufficient livelihood, farming has long been driven by a desire to pursue an independent lifestyle, free from dependence on markets and governments (van der Ploeg 2010). Traditional-ICLS practices enable this self-sufficiency and autonomy by producing all of the necessary inputs to production, as well as a diversity of food sources (Ryschawy et al. 2013, Coquil et al. 2014).

In the U.S., Old Order Amish farmers continue to pursue traditional-ICLS because of social controls on the introduction of new technologies, e.g., synthetic inputs or heavy machinery, and a refusal of government assistance, such as subsidized insurance (Stinner et al. 1989). Similar trends can be found for Anabaptist farming communities throughout the world. In some cases, self-sufficiency has been forced upon communities because of economic conditions. Even within commercial agricultural production regions, farmers with fewer assets and less access to government resources or markets maintain traditional-ICLS as a closed loop farming system to provide sufficient food for household consumption and avoid input purchases. Livestock, in particular, ensure a source of fertilization for crop production and serve as a savings account for times of crisis (Herrero et al. 2010, Garrett et al. 2017c).

Biophysical conditions can reinforce cultural tendencies. Traditional-ICLS are often maintained in less-favored areas to overcome the resource constraints that inhibit specialization (Schiere et al. 2002, Ryschawy et al. 2013). In Europe and the U. S., farmers operating in more marginal areas have maintained traditional-ICLS often because they have no other choice (Ryschawy et al. 2013). In South Asia, water scarcity from climate change is creating pressure to transition from rice and wheat systems to ICLS with cattle or buffalo (Herrero et al. 2010). At a smaller scale, higher within-farm heterogeneity, e.g., the presence of steep slopes, poorly drained soils, and wetlands, etc., supports the use of traditional-ICLS to take advantage of the entire landscape and manage variability (Ruben and Pender 2004). This heterogeneity has also supported the reemergence of new-ICLS in other regions, as noted below.

\section{Opportunities for new-ICLS emergence within the dominant agricultural regime}

Rising environmental awareness, changes in agricultural policy, and changes in input and product markets have created opportunities for new-ICLS to increase globally (Bell and Moore 2012, Gil et al. 2016, Garrett et al. 2017b, Cortner et al. 2019). These opportunities could be considered as induced from grassroots niches. They are constrained by the relative prevalence of livestock in a region, local biophysical conditions (e.g., water scarcity, topography), the profitability of monoculture systems during high price periods, and cultural preferences (Bonaudo et al. 2014, Garrett et al. 2017b; Table 1). An additional stimulus for new-ICLS adoption comes from the rise of peasant movements calling for self-sufficiency and autonomy in reaction to globalization, such as La Via Campesina and Fédération Associative pour le Développement de l'Emploi Agricole et Rural
(FEDEAR; Dumont et al. 2016). In seeking self-sufficiency for cost-savings and autonomy, these social movements often promote more holistic and agro-ecological farm-management approaches that reduce reliance on external inputs, including types of new-ICLS (Bonaudo et al. 2014, Dumont et al. 2016).

Other opportunities are coming from the regime itself, promoted by institutionalized actors. In the EU, the second pillar of the Common Agriculture Policy (CAP) has been supporting agroenvironmental practices, in particular, the maintenance of grasslands and seminatural areas. The second pillar has thus encouraged the persistence of grazing systems in less favored areas and the emergence of new-ICLS. Since 2013, 30\% of the EU budget for CAP direct subsidies has been allocated to environmental-friendly practices such as crop diversification through the greening of the CAP (European Commission 2018a), but this subsidy does not take into account the level of integration between crops and animals. In France, the 4/1000 initiative, an effort to increase soil carbon stocks by $0.4 \%$ per year (https:// www.4p1000.org/) and the Food and Agriculture Modernization Law (Bellon and Ollivier 2018) both support more multifunctional practices and agroecology, in particular the improvement of soil quality through legume-based diversified rotations and reintegration of livestock into cropping systems. In European agricultural research agencies, new participatory design efforts involving farmers and advisers are also attempting to foster greener agriculture (Martin et al. 2016). In the Netherlands there has been a movement toward "circular agriculture," emphasizing the use of residuals of agricultural biomass and food processing within the food system to reduce dependency on chemical fertilizers and remote livestock feeds (Thigssen 2018). Feeding nonedible crop by-products to animals has also been proposed in other places as an option to limit feed-food competition (van Zanten et al. 2016).

In Brazil, new-ICLS is being promoted by the government's Low Carbon Agriculture (ABC) Plan and increasing restrictions on native vegetation clearing that are linked to Brazil's broader international commitment to reduce national greenhouse gas emissions (Gil et al. 2016). The ABC program provides subsidized loans for the adoption of ICLS to combat soil degradation and recuperate degraded pastures, thereby improving animal performance and reducing the amount of time it takes to get cattle to slaughter weight and thus emissions per unit of food produced (Observatorio ABC 2016). Restrictions on forest clearing have incentivized the adoption of ICLS to increase productivity on the existing land area (Garrett et al. 2018, Cortner et al. 2019).

In New Zealand, beef and sheep are highly abundant relative to cropping because of biophysical limitations in the landscape, such as unfavorable soils with low water holding capacity. Yet, these same soil and water constraints also limit forage production, creating incentives for beef and sheep farmers to seek out additional grazing areas to supplement their livestock, i.e., rows between grape vines or stubble of cover and forage crops. Changes in nutrient emission policies and gradual recognition of the economic and environmental benefits of such practices in improving nutrient management have helped foster this integration (Niles et al. 2018).

In Australia, various research and adoption programs, e.g., Grain and Graze, have aimed to increase integration of beef and sheep 
Table 1. Local context factors supporting or inhibiting for persistence of traditional-ICLS (integrated crop and livestock systems) or reemergence of new-ICLS across different countries (justifications for categories and rankings provided in Appendix 2).

\begin{tabular}{|c|c|c|c|c|c|c|c|}
\hline \multirow[b]{2}{*}{ Cases } & \multicolumn{2}{|c|}{ Traditional-ICLS persistence } & \multicolumn{5}{|c|}{ New-ICLS reemergence } \\
\hline & $\begin{array}{l}\text { Amish farms in } \\
\text { United States }\end{array}$ & $\begin{array}{l}\text { Family farms in } \\
\text { Brazil }\end{array}$ & $\begin{array}{c}\text { Pastures and } \\
\text { croplands in } \\
\text { Brazil } \\
\end{array}$ & $\begin{array}{c}\text { Nonpastoral } \\
\text { areas in } \\
\text { Australia } \\
\end{array}$ & $\begin{array}{l}\text { Nonpastoral } \\
\text { areas in New } \\
\text { Zealand } \\
\end{array}$ & $\begin{array}{l}\text { Agro-ecological } \\
\text { farms France }\end{array}$ & $\begin{array}{l}\text { Carbon farming } \\
\text { in United States }\end{array}$ \\
\hline Main objectives & $\begin{array}{c}\text { Maintain } \\
\text { autonomy } \\
\text { Respect for } \\
\text { community } \\
\text { values and } \\
\text { norms } \\
\text { Control or avoid } \\
\text { new technology }\end{array}$ & $\begin{array}{l}\text { Reduce cost and } \\
\text { economic risk } \\
\text { Household } \\
\text { consumption }\end{array}$ & $\begin{array}{c}\text { Reduce } \\
\text { deforestation } \\
\text { Increase } \\
\text { productivity and } \\
\text { profits } \\
\text { Reduce costs } \\
\text { Maintain social } \\
\text { status }\end{array}$ & $\begin{array}{c}\text { Resilience } \\
\text { Reduce costs } \\
\text { Increase profits }\end{array}$ & $\begin{array}{c}\text { Reduce } \\
\text { pollution } \\
\text { Reduce costs }\end{array}$ & $\begin{array}{l}\text { Self-sufficiency } \\
\text { at farm or } \\
\text { territorial levels } \\
\text { Reduce costs } \\
\text { and variability } \\
\text { of inputs cost } \\
\text { Reduce } \\
\text { pollution }\end{array}$ & $\begin{array}{l}\text { Climate resilience } \\
\text { Reduce costs } \\
\text { Reduce pollution }\end{array}$ \\
\hline \multicolumn{8}{|c|}{$\begin{array}{l}\text { Factors supporting ICLS } \\
\text { Pull factors coming from the landscape, i.e., landscape opportunities }\end{array}$} \\
\hline $\begin{array}{l}\text { Preference for } \\
\text { autonomy }\end{array}$ & ++++ & +++ & ++ & +++ & +++ & +++ & ++ \\
\hline $\begin{array}{l}\text { Targeted by climate or } \\
\text { pollution mitigation } \\
\text { policy }\end{array}$ & + & ++ & +++ & ++ & ++ & +++ & $\begin{array}{l}++(\text { occurs at } \\
\text { state level })\end{array}$ \\
\hline $\begin{array}{l}\text { Highly variable } \\
\text { topography, climate, or } \\
\text { soil }\end{array}$ & ++ & ++ & ++ & +++ & ++ & ++ & + \\
\hline $\begin{array}{l}\text { Agricultural research } \\
\text { focused on } \\
\text { sustainability and } \\
\text { climate }\end{array}$ & + & + & +++ & ++ & ++ & ++ & ++ \\
\hline \multicolumn{8}{|c|}{ Push factors coming from the niches, i.e., niche opportunities } \\
\hline $\begin{array}{l}\text { Industry and civil } \\
\text { society initiatives } \\
\text { promoting ICLS }\end{array}$ & +++ & + & ++ & ++ & ++ & + & ++ \\
\hline $\begin{array}{l}\text { Differentiated value } \\
\text { chains and eco- or } \\
\text { social labels }\end{array}$ & ++ & + & + & + & ++ & ++ & +++ \\
\hline \multicolumn{8}{|c|}{$\begin{array}{l}\text { Absence of pull factors coming from the landscape, i.e., landscape opportunities } \\
\text { Abctors inhibiting ICLS }\end{array}$} \\
\hline $\begin{array}{l}\text { Lack of supply chain } \\
\text { infrastructure or } \\
\text { marketing } \\
\text { opportunities }\end{array}$ & ++ & +++ & +++ & ++ & + & +++ & ++ \\
\hline High cost of labor & + & + & ++ & +++ & +++ & +++ & ++ \\
\hline $\begin{array}{l}\text { High prices of } \\
\text { synthetic inputs and } \\
\text { fuel or feed }\end{array}$ & + & + & ++ & +++ & ++ & +++ & +++ \\
\hline $\begin{array}{l}\text { Protectionist policies } \\
\text { (e.g., insurance, } \\
\text { subsidies) }\end{array}$ & + & + & + & + & + & +++ & +++ \\
\hline $\begin{array}{l}\text { Food safety } \\
\text { regulations restricting } \\
\text { integration }\end{array}$ & ++ & + & + & + & + & ++ & +++ \\
\hline Absence of push factors c & coming from the nic & ches, i.e., niche oppo & rtunities & & & & \\
\hline $\begin{array}{l}\text { Lack of ICLS farm } \\
\text { trials or } \\
\text { demonstrations }\end{array}$ & + & ++ & ++ & ++ & +++ & +++ & +++ \\
\hline $\begin{array}{l}\text { Lack of farmer } \\
\text { networks to share } \\
\text { knowledge on ICLS }\end{array}$ & + & + & ++ & ++ & + & ++ & +++ \\
\hline $\begin{array}{l}\text { Average inhibiting } \\
\text { factor score }\end{array}$ & ++ & ++ & +++ & +++ & +++ & +++ & ++ \\
\hline $\begin{array}{l}\text { Average supporting } \\
\text { factor score }\end{array}$ & ++ & + & ++ & ++ & ++ & +++ & +++ \\
\hline
\end{tabular}


with crop production by improving the profits, reducing environmental impacts, and building social capital in ICLS via the adoption of best management practices (Price and Hacker 2009). A major objective of this program was to improve "whole farm knowledge" and promote researcher-to-farmer knowledge networks via annual research and extension forums (Hacker et al. 2009). The program is credited with the successful adoption of new-ICLS practices, e.g., dual-purpose crops, improved forage systems, and pasture rotations (Price and Hacker 2009). As with New Zealand, landscape heterogeneity has also been a major impetus for adoption of new-ICLS, leading to the incorporation of livestock areas to take advantage of topographical and soil features that are not suitable for cropping (Lacoste et al. 2018).

Given the technical, labor, and organizational barriers to the adoption of new-ICLS on individual farms, as well as regimeinduced institutional barriers such as limited marketing channels (IPES Food 2015, Martin et al. 2016), groups of farmers are now developing localized exchanges of crops and grazing services, i.e., territorial-ICLS (Meynard et al. 2013, Magrini et al. 2016). Niches of this type have been observed in France (Ryschawy et al. 2017), the Netherlands, Finland (Hacker et al. 2009), the U.S., and New Zealand. For example, wine grape growers in the U.S. contract sheep grazers to reduce their mowing and herbicide usage ( $\mathrm{J}$. Ryschawy, personal observation), while sheep producers in New Zealand pay wine-grape growers to graze their herd in the vineyard to manage forage scarcity (Niles et al. 2018).

\section{Regime factors inhibiting new-ICLS emergence}

Many of the same regime factors that encouraged traditionalICLS retirement have restricted farmers' incentives and ability to adopt new-ICLS (Table 1). Price and income supports for specialized agricultural production, biofuels mandates for agricultural crops, and subsidized insurance programs that shield farmers from ecological, climate, and market risks all disincentivize new-ICLS adoption (O'Donoghue et al. 2009, de Gorter et al. 2015, Lark et al. 2015). Food safety restrictions prohibiting animals in cropping areas make it illegal to practice certain forms of ICLS (Garrett et al. 2017b). Likewise, segregated-HIA systems are favored by easy access to synthetic nitrogen in most developed regions and market failures (environmental costs are not accounted for) that keep production costs artificially low.

Additional regime factors arising from decades of retirement including knowledge gaps, supply chain lock-in, and habits of specialization further constrain new-ICLS adoption (Table 1). ICLS are often perceived to have lower profitability and involve higher (and more skilled) labor requirements and upfront costs than specialized systems (Cortner et al. 2019), even though returns on investment have been shown to be faster and higher than investments in specialized systems (dos Reis et al. 2019). In more remote agricultural regions, both perceived and actual gaps for marketing diversified products limit ICLS adoption (Gil et al. 2016, EIP-AGRI 2017, Ryschawy et al. 2017, Cortner et al. 2019). Many farmers have reported that they lack technical knowledge or experience to adopt new-ICLS appropriate to their context (Allen et al. 2007, Sulc and Franzluebbers 2014, EIP-AGRI 2017). The exchange or hiring of labor is challenged by a lack of crosstraining of individuals with both livestock grazing and crop expertise (Garnett et al. 2017). Furthermore, the specialized nature of many research and advisory systems centered around individual crop or livestock commodities fails to provide adequate extension services to train farmers for new-ICLS management. Similarly, regulations, credit mechanisms, and supply-chains are often focused on single commodities, making financing and marketing of ICLS challenging (Gil et al. 2016, Cortner et al. 2019), though direct marketing can help overcome this challenge for some products, such as fresh produce, meat, and wine (e.g., Vidal 2019). In terms of culture, lifestyle preferences for either crop or livestock management based on family experience and seasonal labor requirements and links between personal identity and current farming systems, may limit adoption among certain individuals (Garrett et al. 2017c, Cortner et al. 2019).

Higher perceived managerial intensity reduces farmers' incentives to cooperate for exchanges to achieve territorial-ICLS (EIPAGRI 2017). Planning, operational and monitoring costs limit the feasibility of such exchanges around the world (Asai et al. 2018). Organizing exchanges requires trust among partners, overcoming legal constraints (e.g., taxes on transactions, manure transportation norms), and organizing appropriate governance to face uncertainties (e.g., variability in feed quality or quantity, animal management in partners' fields). The identification of cost-benefit trade-offs between individual and collective levels is of primary importance and requires tailored support from research or extension services (Ryschawy et al. 2019).

\section{LEVERS FOR REINTEGRATION OF CROP AND LIVESTOCK SYSTEMS WORLDWIDE}

Levers for furthering the adoption of various types of innovative ICLS include both pull and push factors that could disrupt the existing agricultural regime and destabilize locked-in specializedHIA practices and associated value chains (Fig. 4). Pull factors are conditions and changes in the landscape and regime that create a need for innovation (top-down processes). Push factors are bottom-up processes that emerge from the niche context, i.e., local knowledge, social, and institutional changes, to supply and support new technologies and can address top-down needs. Push factors alone are often not enough to disrupt the socio-technical regime and bring about practice change, but are often critical in testing and refining technologies to be ready for adoption should other drivers sufficiently favor a shift in practice (Turnheim and Geels 2012). System transformation is most likely when policy mixes include both push and pull levers that reinforce each other, and when promotion of a new system is coupled with creative disruption of the old regime (Kivimaa and Kern 2016).

\section{Pull factors for ICLS}

Existing agricultural research paradigms often prioritize yields over whole farm outcomes, such as economic risk reduction, resilience, production diversity, cost minimization, and input efficiency. This yield-centric approach downplays objectives that are important to farmers and society and ignores externalities. Participatory design would allow the exchange of knowledge on technical, social, and policy issues to regionally appropriate models of ICLS. Such interactive and multiactor design approaches are currently favored by the European Commission under the European Partnership Innovation through grants for projects that are supposed to involve multiple stakeholders in a local area over several years (European Commission 2018b). Research programs should be redesigned to focus more on whole farm outcomes and participatory design (Meynard et al. 2017). 
Fig. 4. Pull and push factors that could disrupt or reform the existing agricultural regime and promote reemergence of ICLS (integrated crop and livestock systems). The size of the arrows reflects their relative individual strength. For example, some push factors, such as field trials, are individually small in influence, but collectively gain force when embedded into farmer knowledge systems to help promote adoption of New-ICLS. HIA, high input agriculture.

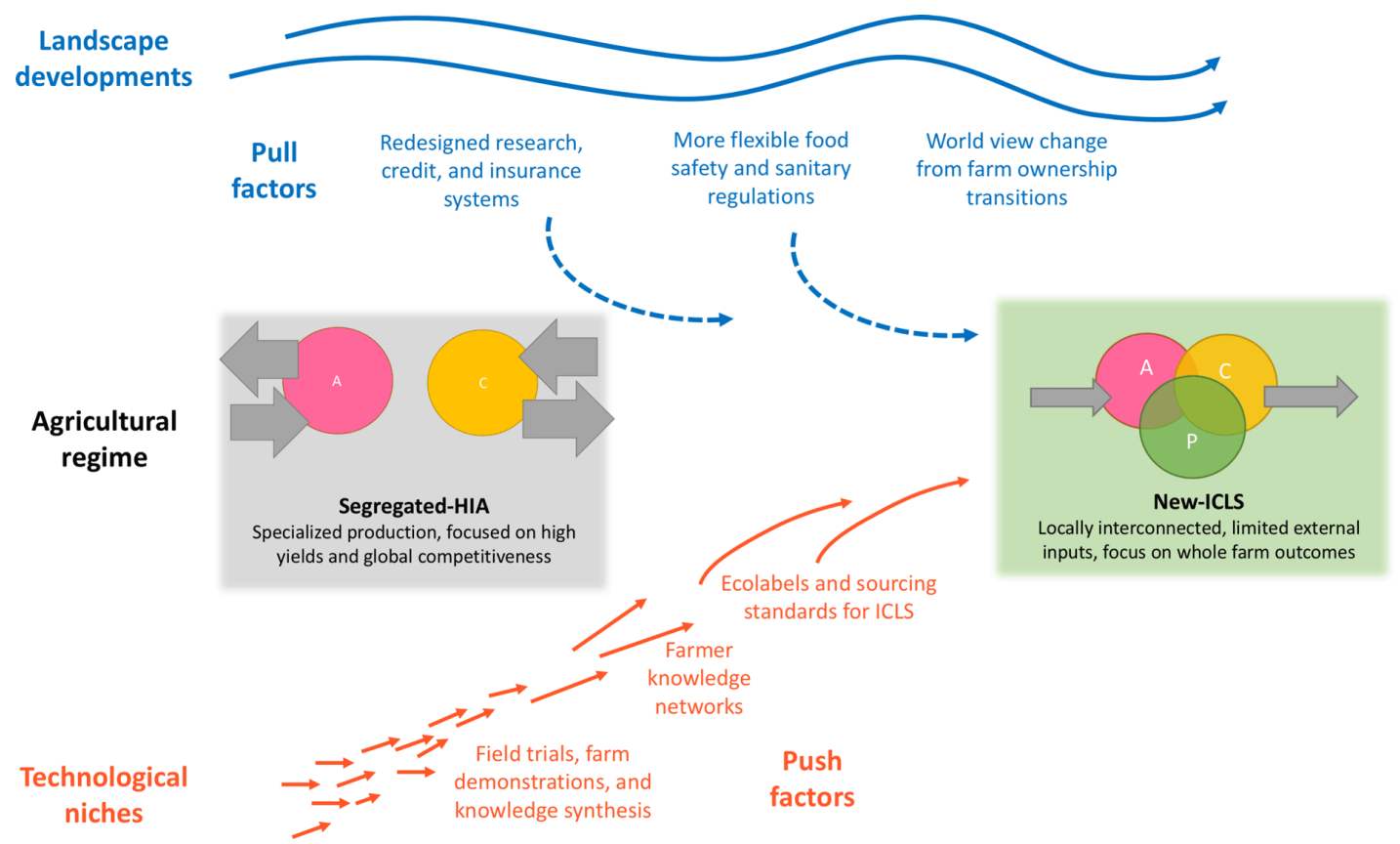

Credit mechanisms that only cover planting costs or the purchase of new machinery and stock may be inadequate for transforming farming practices from specialized systems to new-ICLS because of inadequate funding levels, high interest rates, and short-term payback periods (Garrett et al. 2019). Existing funding lines prioritize annual profit outcomes over risk reduction or have inadequate data about the financial returns for ICLS. Additionally, new credit sources are often inadequately linked to the provision of technical assistance to promote adoption. This assistance is necessary since the relevant knowledge and skills for integration are often absent after decades of specialization (Price and Hacker 2009). These shortcomings have been documented even in Brazil, where credit programs are targeted at improving new-ICLS adoption (Gil et al. 2016, Observatorio ABC 2016, Cortner et al. 2019). Credit systems should be adjusted to take into account a longer term view of whole farm outcomes with system transformation, including a reduction of economic risk and negative social externalities relative to private returns. Credit lines should be developed to encourage territorial-ICLS through collective subsidies.

Profit margin and yield insurance programs serve an important social role in reducing farmers' vulnerability to market and weather variability. However, in regions such as the U.S., farm insurance programs offer payouts for only a limited number of crops and do not base premiums on diversification or management changes that reduce risk of yield or income variability (NSAC 2017). In contrast, in Australia and New
Zealand, farmers are exposed to high levels of climate and commodity price variability, but do not have the benefit of a federal crop insurance system or other substantial market protections. Thus, the income diversification and reduced input costs that ICLS systems provide serve as a critical risk mitigation strategy for farmers. In the European Union, crop premiums have enabled productivity increases, but in some cases led to perverse incentives, e.g., crops could be planted but left unharvested in the interest of earning a premium. Crop insurance programs should be improved to better take into account farm diversity and risk profiles and or eliminated to reduce perverse outcomes.

In some regions, regulations inhibit the trade and transportation of crop by-products for use as animal feed, the use of animal waste for fertilization, or the presence of animals grazing in areas used to grow crops (Garrett et al. 2017b). Even where integration is legal, the fear of liability discourages experimentation with most types of ICLS (Garrett et al. 2017b). In the EU, the use of food waste as livestock feed is prohibited. This is a legacy of foot-andmouth disease outbreaks, which were thought to be caused by feeding pigs uncooked food waste, even though cooked food waste has been proven to be a safe and efficient source of feed (Gaudré et al. 2013, Zu Ermgassen et al. 2016, Dumont et al. 2019). In the U.S., food safety regulations prohibit the use of raw manure or the presence/grazing of animals in areas used to produce foods that are consumed directly by humans within 90-120 days of the harvest (FDA 2015). Although the purpose of these regulations is to protect human health, they conflate practices with different 
risks, e.g., using massive quantities of raw chicken manure on spinach fields is likely riskier than grazing sheep in the understories of fruit trees or feeding pigs with treated biscuit waste. Regulations that inhibit a circular economy should be adjusted to allow increased use of farm outputs, while respecting health and environment issues.

Finally, current agricultural transitions are impeded by deeply embedded habits of specialization, farm income, or firm profit maximization priorities, and a lack of awareness about whole farm management and the environmental impacts of existing production systems. As farming systems experience ownership transitions, facilitating land purchases by young farmers could help modify the habits, priorities, and knowledge gaps of current farming cultures.

\section{Push factors}

Successful practices to combine crops and livestock in a sustainable way have been studied by researchers in case studies and experimental plots and farms (Bell and Moore 2012, Sulc and Franzluebbers 2014), yet there is limited information on exactly which locations and practices (types of crops and animals and levels of integration) may be more suitable for new-ICLS. Greater qualitative and quantitative assessment of both successful and unsuccessful examples of new-ICLS on actual farms could provide improved understanding of the conditions underpinning their viability. Demonstration plots on existing farms and field days would also be a powerful tool for motivating adoption. For example, in Brazil, uptake of new-ICLS was substantially higher near locations of ICLS experiments (Gil et al. 2016). Technical assistance at the field scale must be coupled with better training of rural extension workers, farmers, and farm workers. Agricultural research organizations should increase gatherings, organization and knowledge exchange on successful farms that have already adopted ICLS, and work jointly with farmers to develop and disseminate successful forms of new-ICLS, for example via demonstration plots and field days.

Farmers' networks have already proved to be influential at altering perceptions of specific technologies (Prokopy et al. 2008, Lubell et al. 2014). Still, development of multiactor and cross-sectoral groups could be a further step in supporting innovation niches (Pigford et al. 2018). For instance, recent participatory research has allowed farmers to build scenarios of territorial-ICLS in two areas of southwestern France (Moraine et al. 2017, Ryschawy et al. 2019). Crop farmers and livestock farmers wanted to decrease their dependence on external inputs by buying feed and fertilizer from their neighbors. Win-win economic, environmental, and social scenarios were identified through collective organization and trust building (Asai et al. 2018). Power asymmetries between participants were addressed through the use of tools such as roundtables and the comanagement of the project between a farmer, an adviser, and a researcher, although it remains a significant challenge for such exercises. To improve the success of participative design approaches, further work on farmers' motivations to manage new-ICLS or territorial-ICLS should be developed (Ryschawy et al. 2019). Connecting farmers and stakeholders, e.g., cooperative leaders, policy makers, and consumers, could also have the additional benefit of improving lobbying for policies and regulations that favor new-ICLS or territorial-ICLS, as exemplified by lobbying for grass-fed beef
(Soil Carbon Cowboys), agroforestry (Arbores et Paysages), and conservation agriculture (Goulet and Vinck 2012). Cooperatives could play a role as change agents in the organization of local exchanges among farmers and broader diversification of products by identifying new markets (Yang et al. 2014). Agricultural researchers and practitioners should foster knowledge exchange regarding new-ICLS between farmers and other cross-sectoral stakeholders.

The possibility to market new-ICLS products as local and green, leading to the creation of a differentiated market in crop and livestock value chains could be a powerful push factor in regions where consumers already have strong environment or local food preferences. Such niche systems have emerged in Finland, France, the U.S., and New Zealand, including the marketing of sheep in vineyards as sustainable viticulture in the latter two countries (EIP-AGRI 2017, Niles et al. 2018). However, these marketing campaigns may risk oversupply and falling prices without commensurate increases in demand. Value chain upgrading into differentiated markets should be encouraged to incentivize newICLS practices, create a territorial identity for associated products, and create new marketing opportunities for value chain firms that lead in this area. Labeling programs and certifications could help with this effort.

\section{CONCLUSION}

There is substantial evidence that ICLS can help reduce the environmental externalities associated with conventional commercial farming, without declines in profitability or yields, by making progress toward closing the loop in nutrient and energy cycles (Lemaire et al. 2013, Franzluebbers et al. 2014, Garrett et al. 2017a, Ryschawy et al. 2017). Yet across most regions they have been declining for several decades and remain rare as a proportion of global agricultural area. This paper provides a historical and international perspective on multilevel factors that have contributed to the decline of ICLS within major commercial production regions. We also synthesize conditions that have fostered their persistence and reemergence in some areas, which provides a basis for understanding how to overcome barriers to reintegration and facilitate a socio-political environment where ICLS are supported.

Using a multilevel perspective, we identified one dominant global trajectory of ICLS retirement and two niches: traditional-ICLS persistence and new-ICLS emergence from both grassroots efforts and institutionalized regime players that could be leveraged into wider adoption. The dominant trajectory of ICLS retirement in commercial agricultural systems is linked to global and national landscape factors: a lessening of trade barriers, declining agricultural prices relative to wages, artificially low prices for synthetic inputs, e.g., fuel, fertilizers, and pesticides, and agricultural subsidies oriented toward specialized systems. These processes have favored the development of segregated-HIA, and semi-ICLS, where only minimal integration occurs.

Amid this broader agricultural regime, traditional-ICLS have persisted in regions where unique cultural considerations, i.e., religious beliefs spurning technological change, have offset incentives to compete globally in specialized segregated-HIA production or where protectionist government policies in the Global North have buffered farmers from market changes, especially in less-favored soil-climatic contexts. In other regions, 
new-ICLS have emerged with two different pathways: (i) adoption of commercial cropping systems in regions with a large livestock sector and a legacy of traditional-ICLS, and (ii) adoption of newICLS in regions where environmental concerns and changing environmental policies are encouraging more sustainable agriculture via diversification or sustainable intensification. The first pathway tends to occur in regions with less government protections for farmers and difficult livestock grazing conditions that require additional feed sources, e.g., Australia and New Zealand, leading to seasonal integration of beef and sheep farming within arable or viticulture cropland. The latter pathway is occurring for a large diversity of systems, where environmentalfriendly practices are being encouraged by both institutionalized regime players and grassroots movements, e.g. Brazil, Europe, and the U.S.)

Our study is limited by data availability on agricultural management practices, the geographical scale at which global data on ICLS and agricultural management are available, and the local knowledge of participants in our workshop and analysis, which spans Australia, Brazil, France, Netherlands, New Zealand, the U.S., and Canada, but lacks representation from other major commercial production regions (EIP-AGRI 2017). Because of a focus on national-scale aggregate trends, major knowledge gaps remain about the precise locations of ICLS and levels of integration between the crop and livestock components. This knowledge gap limits our understanding of the social and ecological drivers of ICLS and their sustainability outcomes. Our international approach underestimates the importance of very local factors and may have failed to capture potentially insightful outlier cases that could have illuminated additional important push and pull factors.

Nevertheless, our diagnosis and synthesis of existing cases from a multilevel perspective highlights several key problems with the social and ecological landscape that encourage locked-in agricultural regimes and inhibit new-ICLS or territorial-ICLS adoption and identifies leverage points that could be used to improve the adoption and sustainability of ICLS. This approach is a much needed complement to continued case study work and participatory design efforts, to identify worldwide opportunities and barriers to recoupling crop and livestock systems that emerge from complex multilevel interactions and historical legacies. To increase the level of ICLS adoption and improve the sustainability of existing agricultural regimes in commercial agricultural production systems, we suggest a combination of major structural changes that can provide top-down impetus to adjust agricultural management and encourage a "creative disruption" of the existing regime (Kivimaa and Kern 2016). This should be coupled with more small-scale, bottom-up efforts that can help support wider scale adoption of existing niche ICLS reemergence.

On the structural side (pull factors), we encourage a redesign of research programs, credit systems, and insurance programs to focus more on whole farm outcomes over longer time horizons in a way that ensures farmers' own their risk minimization efforts. We also suggest that current regulations be adjusted to focus more on a circular economy, with greater flexibility in addressing food safety concerns, rather than outright prohibitions on integration and material reuse. To disrupt current practices, governance changes would need to be ambitious, leading to the abolishment or replacement of existing policies, rather than just layering new incentives on existing policies that continue to support lock-in (Kivimaa and Kern 2016).

From a bottom-up perspective, we suggest that agricultural research organizations expand the number of field trials and demonstration farms and make more of an effort to gather, organize, synthesize, and disseminate information on successful ICLS outcomes in existing farms through knowledge exchange networks between farmers and other stakeholders' efforts. We also encourage researchers and practitioners to engage with farmers about design approaches to implement successful new-ICLS. Greater effort should be made to brand ICLS as sustainable agriculture and educate consumers through the development of new sourcing standards and social- and eco-labels and to quantify the sustainability credentials required to garner market support for differentiated products. Finally, there is an urgent need to improve government data collection and remote sensing efforts to characterize and assess the management of global pasture and livestock areas (Garrett et al. 2017a). These data are needed to better understand current levels of ICLS adoption, their drivers, and their ecological outcomes (Manabe et al. 2018).

Given the power of entrenched interests within the existing regime, it is unlikely that these levers will be easy to establish because they involve value trade-offs and changes in the distribution of costs and benefits associated with global food systems (IPES Food 2015). Indeed few examples of policy replacement for food system transformation can be found in recent history (Kivimaa and Kern 2016). Yet, climate change, increasing market volatility, global geopolitical restructurings associated with income growth, and changing demand may create new opportunities for change by encouraging practices, including ICLS, that provide farmers with greater resilience to all types of external shocks (Garrett et al. 2017a). Policy makers and practitioners should proactively address innovation system reform by pursuing the above described pull and push levers to seize this opportunity for improved sustainability.

\section{AUTHOR CONTRIBUTIONS}

Rachael Garrett and Julie Ryschawy contributed equally to the article conception, figures, and writing. Rachael Garrett led the international workshop underpinning the article. All other authors contributed to the development of the ideas and specific case studies included the study, as well as the writing and editing of the manuscript.

Responses to this article can be read online at: http://www.ecologyandsociety.org/issues/responses. $\mathrm{php} / 11412$

\section{Acknowledgments:}

This study was supported by the United States National Science Foundation Grant No. 1415352; the Thomas Jefferson Fund Make the Planet Great Again program, the Sustainability Science Program at Harvard University; and the Italian Ministry for Environment, Land and Sea. This work and the workshop that supported it was made possible through close cooperation and 
collaboration with the Brazilian Agricultural Research Corporation (Embrapa). We would also like to thank the Global Development Policy Center at Boston University for supporting the students who worked on this project.

\section{LITERATURE CITED}

Allen, V. G., M. T. Baker, E. Segarra, and C. P. Brown. 2007. Integrated irrigated crop-livestock systems in dry climates. Agronomy Journal 99:346-360. https://doi.org/10.2134/agronj2006.0148

Allen, V. G., C. P. Brown, R. Kellison, E. Segarra, T. Wheeler, P. A. Dotray, J. C. Conkwright, C. J. Grenn, and V. Acosta-Martinez. 2005. Integrating cotton and beef production to reduce water withdrawal from the Ogallala Aquifer in the Southern High Plains. Agronomy Journal 97(2):556-567. https://doi.org/10.2134/ agronj2005.0556

Asai, M., M. Moraine, J. Ryschawy, J. de Wit, A. K. Hoshide, and G. Martin. 2018. Critical factors for crop-livestock integration beyond the farm level: a cross-analysis of worldwide case studies. Land Use Policy 73:184-194. https://doi.org/10.1016/j. landusepol.2017.12.010

Balbino, L. C., A. O. Barcellos, and L. F. Stone. 2011. Marco referencial integração lavoura-pecuária-floresta. Embrapa, Brasilia, DF, Brazil.

Barbieri, C., E. Mahoney, and L. Butler. 2008. Understanding the nature and extent of farm and ranch diversification in North America. Rural Sociology 73(2):205-229. https://doi. org/10.1526/003601108784514543

Bell, L. W., and A. D. Moore. 2012. Integrated crop-livestock systems in Australian agriculture: trends, drivers and implications. Agricultural Systems 111:1-12. https://doi. org/10.1016/j.agsy.2012.04.003

Bellon, S., and G. Ollivier. 2018. Institutionalizing agroecology in France: social circulation changes the meaning of an idea. Sustainability 10(5):1380. https://doi.org/10.3390/su10051380

Bonaudo, T., A. B. Bendahan, R. Sabatier, J. Ryschawy, S. Bellon, F. Leger, D. Magda, and M. Tichit. 2014. Agroecological principles for the redesign of integrated crop-livestock systems. European Journal of Agronomy 57:43-51. https://doi.org/10.1016/ j.eja.2013.09.010

Bradshaw, B. 2004. Plus c'est la meme chose? Questioning crop diversification as a response to agricultural deregulation in Saskatchewan, Canada. Journal of Rural Studies 20(1):35-48. https://doi.org/10.1016/S0743-0167(03)00033-0

Carvalho, J. L. N., G. S. Raucci, L. A. Frazão, C. E. P. Cerri, M. Bernoux, and C. C. Cerri. 2014. Crop-pasture rotation: a strategy to reduce soil greenhouse gas emissions in the Brazilian Cerrado. Agriculture, Ecosystems \& Environment 183:167-175. https://doi. org/10.1016/j.agee.2013.11.014

Chadwick, D., S. Sommer, R. Thorman, D. Fangueiro, L. Cardenas, B. Amon, and T. Misselbrook. 2011. Manure management: implications for greenhouse gas emissions. Animal Feed Science and Technology 166-167:514-531. https://doi. org/10.1016/j.anifeedsci.2011.04.036
Coomes, O. T., B. L. Barham, G. K. MacDonald, N. Ramankutty, and J.-P. Chavas. 2019. Leveraging total factor productivity growth for sustainable and resilient farming. Nature Sustainability 2:22-28. https://doi.org/10.1038/s41893-018-0200-3

Coquil, X., P. Béguin, and B. Dedieu. 2014. Evolution towards mixed-crop organic dairy systems: reinforcement of crop/ livestock interfaces. Economie Rurale 339/340:81-94. https://doi. org/10.4000/economierurale.4239

Cortner, O., R. D. Garrett, J. F. Valentim, J. Ferreira, M. T. Niles, J. Reis, and J. Gil. 2019. Perceptions of integrated crop-livestock systems for sustainable intensification in the Brazilian Amazon. Land Use Policy 82:841-853. https://doi.org/10.1016/j. landusepol.2019.01.006

Cunfer, G. 2004. Manure matters on the Great Plains frontier. Journal of Interdisciplinary History 34(4):539-567. https://doi. org/10.1162/002219504773512534

de Gorter, H., D. Drabik, and D. R. Just. 2015. Measures of biofuel policy impact on food commodity prices. Pages 47-66 in The economics of biofuel policies. Palgrave Macmillan, New York, New York, USA. https://doi.org/10.1057/9781137414854_4

Devendra, C., and D. Thomas. 2002. Crop-animal interactions in mixed farming systems in Asia. Agricultural Systems 71 (1-2):27-40. https://doi.org/10.1016/S0308-521X(01)00034-8

Dimitri, C., A. B. Effland, and N. C. Conklin. 2005. The 20th century transformation of U.S. agriculture and farm policy. U.S. Department of Agriculture, Economic Research Service, Washington, D.C., USA.

dos Reis, J. C., M. Y. T. Kamoi, D. Latorraca, R. F. F. Chen, M. Michetti, F. J. Wruck, R. D. Garrett, J. F. Valentim, R. de Aragão Ribeiro Rodrigues, and S. Rodrigues-Filho. 2019. Assessing the economic viability of integrated crop-livestock systems in Mato Grosso, Brazil. Renewable Agriculture and Food Systems. https:// doi.org/10.1017/S1742170519000280

Dumont, A. M., G. Vanloqueren, P. M. Stassart, and P. V. Baret. 2016. Clarifying the socioeconomic dimensions of agroecology: between principles and practices. Agroecology and Sustainable Food Systems 40(1):24-47. https://doi.org/10.1080/21683565.2015.1089967

Dumont, B., J. Ryschawy, M. Duru, M. Benoit, V. Chatellier, L. Delaby, C. Donnars, P. Dupraz, S. Lemauviel-Lavenant, B. Méda, D. Vollet, and R. Sabatier. 2019. Associations among goods, impacts and ecosystem services provided by livestock farming. Animal 13(8):1773-1784. https://doi.org/10.1017/S1751731118002586

EIP-AGRI. 2017. Focus group mixed farming systems: livestock/ cash crops. EIP-AGRI, Bruxelles, Belgium.

Embrapa. 2016. Rede de Fomento ILPF. Embrapa, Brasilia, Brazil. [online] URL: http://redeilpf.com.br/rede-de-fomentoilpf

Entz, M. H., W. D. Bellotti, J. M. Powell, S. V. Angadi, W. Chen, K. H. Ominski, and B. Boelt. 2005. Evolution of integrated croplivestock production systems. Pages 137-148 in D. A. McGilloway, editor. Grassland: a global resource. Wageningen Academic, Wageningen, The Netherlands. 
European Commission. 2018a. Greening. European Commission Agriculture and Rural Development, Brussels, Belgium.

European Commission. 2018b. About EIP-AGRI. European Commission, Brussels, Belgium.

Faust, D. R., S. Kumar, D. W. Archer, J. R. Hendrickson, S. L. Kronberg, and M. A. Liebig. 2018. Integrated crop-livestock systems and water quality in the Northern Great Plains: review of current practices and future research needs. Journal of Environmental Quality 47(1):1-15. https://doi.org/10.2134/ jeq2017.08.0306

Foley, J. J. A., R. DeFries, G. P. Asner, C. Barford, G. Bonan, S. R. Carpenter, F. S. Chapin, M. T. Coe, G. C. Daily, H. K. Gibbs, J. H. Helkowski, T. Holloway, E. A. Howard, C. J. Kucharik, C. Monfreda, J. A. Patz, I. C. Prentice, N. Ramankutty, and P. K. Snyder. 2005. Global consequences of land use. Science 309 (5734):570-574. https://doi.org/10.1126/science.1111772

Food and Agriculture Organization (FAO). 2017. Food and Agriculture Organization online statistical service: production and trade statistics. FAO, Rome, Italy. [online] URL: http://www.fao. org/faostat/

Food and Drug Administration (FDA). 2015. FSMA final rule on produce safety. FDA, Silver Spring, Maryland, USA.

Franzluebbers, A. J., G. Lemaire, P. C. de Faccio Carvalho, R. M. Sulc, and B. Dedieu. 2014. Toward agricultural sustainability through integrated crop-livestock systems: environmental outcomes. Agriculture, Ecosystems and Environment 190:1-3. https://doi.org/10.1016/j.agee.2014.04.028

Gaitán-Cremaschi, D., L. Klerkx, J. Duncan, J. H. Trienekens, C. Huenchuleo, S. Dogliotti, M. E. Contesse, and W. A. Rossing. 2019. Characterizing diversity of food systems in view of sustainability transitions. A review. Agronomy for Sustainable Development 39:1. https://doi.org/10.1007/s13593-018-0550-2

Garnett, T., C. Godde, A. Muller, E. Röös, P. Smith, I. de Boer, E. zu Ermgassen, M. Herrero, C. van Middelaar, and C. Schader. 2017. Grazed and confused?: ruminating on cattle, grazing systems, methane, nitrous oxide, the soil carbon sequestration question-and what it all means for greenhouse gas emissions. Food Climate Research Network, University of Oxford, Oxford, UK.

Garrett, R. D., T. A. Gardner, T. Fonseca, S. Marchand, J. Barlow, D. Ezzine de Blas, J. Ferreira, A. C. Lees, and L. Parry. 2017c. Explaining the persistence of low income and environmentally degrading land uses in the Brazilian Amazon. Ecology and Society 22(3):27. https://doi.org/10.5751/es-09364-220327

Garrett, R. D., J. Gil, and J. Valentim. 2019. Transferência de tecnologia: desafios e oportunidades para adoção de ILPF na Amazonia [Technology transfer: challenges and opportunities for the adoption of integrated crop-livestock-forestry systems in the Amazon]. Pages 599-615 in D. J. Bungenstab, R. G. Almeida, V. A. Laura, L. C. Balbino, and A. D. Ferreira, editors. Integrated crop-livestock-forestry systems: a Brazilian experience for sustainable farming. Embrapa, Brasilia, DF, Brazil. [online] URL: https://www.infoteca.cnptia.embrapa.br/infoteca/handle/doc/1112650? locale $=$ en

Garrett, R. D., I. Koh, E. F. Lambin, Y. le Polain de Waroux, J. H. Kastens, and J. C. Brown. 2018. Intensification in agriculture- forest frontiers: land use responses to development and conservation policies in Brazil. Global Environmental Change 53:233-243. https://doi.org/10.1016/j.gloenvcha.2018.09.011

Garrett, R. D., E. F. Lambin, and R. L. Naylor. 2013. The new economic geography of land use change: supply chain configurations and land use in the Brazilian Amazon. Land Use Policy 34:265-275. https://doi.org/10.1016/j.landusepol.2013.03.011

Garrett, R. D., M. Niles, J. Gil, P. Dy, J. Reis, and J. Valentim. 2017b. Policies for reintegrating crop and livestock systems: a comparative analysis. Sustainability 9(3):473. https://doi. org/10.3390/su9030473

Garrett, R. D., M. T. Niles, J. D. B. Gil, A. Gaudin, R. ChaplinKramer, A. Assmann, T. S. Assmann, K. Brewer, P. C. de Faccio Carvalho, O. Cortner, R. Dynes, K. Garback, E. Kebreab, N. Mueller, C. Peterson, J. C. Reis, V. Snow, and J. Valentim. $2017 a$. Social and ecological analysis of commercial integrated crop livestock systems: current knowledge and remaining uncertainty. Agricultural Systems 155:136-146. https://doi.org/10.1016/j. agsy.2017.05.003

Garrett, R. D., and X. Rueda. 2019. Telecoupling and consumption in agri-food systems. Pages 115-138 in C. Friis and J. Ø. Nielsen, editors. Telecoupling: exploring land-use change in a globalised world. Palgrave Macmillan, Cham, Switzerland. https:// doi.org/10.1007/978-3-030-11105-2_6

Gaudré, D., C. Roques, and X. Roca. 2013. Utilisation d'un coproduit de biscuiterie dans l'alimentation des porcs en engraissement et en post-sevrage. Journées Recherche Porcine 44:195-196.

Geels, F. W. 2011. The multi-level perspective on sustainability transitions: responses to seven criticisms. Environmental Innovation and Societal Transitions 1(1):24-40. https://doi. org/10.1016/j.eist.2011.02.002

Gil, J. D. B., R. Garrett, and T. Berger. 2016. Determinants of crop-livestock integration in Brazil: evidence from the household and regional levels. Land Use Policy 59:557-568. https://doi. org/10.1016/j.landusepol.2016.09.022

Gil, J. D. B., M. Siebold, and T. Berger. 2015. Adoption and development of integrated crop-livestock-forestry systems in Mato Grosso, Brazil. Agriculture, Ecosystems \& Environment 199:394-406. https://doi.org/10.1016/j.agee.2014.10.008

Goulet, F., and D. Vinck. 2012. Innovation through withdrawal. Contribution to a sociology of detachment. Revue Française de Sociologie 53(2):117-146.

Hacker, R. B., M. J. Robertson, R. J. Price, and A. M. Bowman. 2009. Evolution of mixed farming systems for the delivery of triple bottom line outcomes: a synthesis of the Grain \& Graze program. Animal Production Science 49(10):966-974. https://doi. org/10.1071/AN09091

Henders, S., U. M. Persson, and T. Kastner. 2015. Trading forests: land-use change and carbon emissions embodied in production and exports of forest-risk commodities. Environmental Research Letters 10(12):125012. https://doi.org/10.1088/1748-9326/10/12/125012

Herrero, M., P. K. Thornton, A. M. Notenbaert, S. Wood, S. Msangi, H. A. Freeman, D. Bossio, J. Dixon, M. Peters, J. van de 
Steeg, J. Lynam, P. Parthasarathy Rao, S. Macmillan, B. Gerard, J. McDermott, C. Seré, and M. Rosegrant. 2010. Smart investments in sustainable food production: revisiting mixed croplivestock systems. Science 327(5967):822-825. https://doi. org/10.1126/science. 1183725

Hull, V., and J. Liu. 2018. Telecoupling: a new frontier for global sustainability. Ecology and Society 23(4):41. https://doi. org/10.5751/ES-10494-230441

International Monetary Fund (IMF). 2017. IMF data international financial statistics. IMF, Washington, D.C., USA. [online] URL: https://www.imf.org/en/Data

International Panel of Experts on Sustainable Food Systems (IPES Food). 2015. The case for a new science of sustainable food systems: overcoming barriers to food systems reform. First Report of the International Panel of Experts on Sustainable Food Systems, Brussels, Belgium.

Kearney, J. 2010. Food consumption trends and drivers. Philosophical Transactions of the Royal Society B: Biological Sciences 365(1554):2793-2807. https://doi.org/10.1098/rstb.2010.0149

Kivimaa, P., and F. Kern. 2016. Creative destruction or mere niche support? Innovation policy mixes for sustainability transitions. Research Policy 45(1):205-217. https://doi.org/10.1016/j. respol.2015.09.008

Lacoste, M., R. Lawes, O. Ducourtieux, and K. Flower. 2018. Assessing regional farming system diversity using a mixed methods typology: the value of comparative agriculture tested in broadacre Australia. Geoforum 90:183-205. https://doi. org/10.1016/j.geoforum.2018.01.017

Lark, T. J., J. M. Salmon, and H. K. Gibbs. 2015. Cropland expansion outpaces agricultural and biofuel policies in the United States. Environmental Research Letters 10(4):44003. https://doi. org/10.1088/1748-9326/10/4/044003

Lemaire, G., A. Franzluebbers, P. C. de Faccio Carvalho, and B. Dedieu. 2013. Integrated crop-livestock systems: strategies to achieve synergy between agricultural production and environmental quality. Agriculture, Ecosystems and Environment 190(1):4-8. https://doi.org/10.1016/j.agee.2013.08.009

Lobao, L., and K. Meyer. 2001. The great agricultural transition: crisis, change, and social consequences of twentieth century U.S. farming. Annual Review of Sociology 27:103-124. https://doi. org/10.1146/annurev.soc.27.1.103

Lovell, S. T., S. DeSantis, C. A. Nathan, M. B. Olson, V. E. Méndez, H. C. Kominami, D. L. Erickson, K. S. Morris, and W. B. Morris. 2010. Integrating agroecology and landscape multifunctionality in Vermont: an evolving framework to evaluate the design of agroecosystems. Agricultural Systems 103 (5):327-341. https://doi.org/10.1016/j.agsy.2010.03.003

Lubell, M., M. Niles, and M. Hoffman. 2014. Extension 3.0: managing agricultural knowledge systems in the network age. Society \& Natural Resources 27(10):1089-1103. https://doi. org/10.1080/08941920.2014.933496

Magrini, M.-B., M. Anton, C. Cholez, G. Corre-Hellou, G. Duc, M.-H. Jeuffroy, J.-M. Meynard, E. Pelzer, A.-S. Voisin, and S. Walrand. 2016. Why are grain-legumes rarely present in cropping systems despite their environmental and nutritional benefits? Analyzing lock-in in the French agrifood system. Ecological Economics 126:152-162. https://doi.org/10.1016/j.ecolecon.2016.03.024

Manabe, V. D., M. R. S. Melo, and J. V. Rocha. 2018. Framework for mapping integrated crop-livestock systems in Mato Grosso, Brazil. Remote Sensing 10(9):1322. https://doi.org/10.3390/ rs10091322

Martin, G., M. Moraine, J. Ryschawy, M.-A. Magne, M. Asai, J.P. Sarthou, M. Duru, and O. Therond. 2016. Crop-livestock integration beyond the farm level: a review. Agronomy for Sustainable Development 36:53. https://doi.org/10.1007/s13593-016-0390$\underline{\mathrm{X}}$

McMichael, P. 2005. Global development and the corporate food regime. Pages 265-299 in F. H. Buttel and P. D. McMichael, editors. New directions in the sociology of global development. Emerald Group, Bingley, UK. https://doi.org/10.1016/S1057-1922 (05)11010-5

McMichael, P. 2009. A food regime genealogy. Journal of Peasant Studies 36(1):139-169. https://doi.org/10.1080/03066150902820354

Meynard, J.-M., M.-H. Jeuffroy, M. Le Bail, A. Lefèvre, M.-B. Magrini, and C. Michon. 2017. Designing coupled innovations for the sustainability transition of agrifood systems. Agricultural Systems 157:330-339. https://doi.org/10.1016/j.agsy.2016.08.002

Meynard, J.-M., A. Messéan, A. Charlier, F. Charrier, M. Fares, M. Le Bail, M.-B. Magrini, and I. Savini. 2013. Freins et leviers à la diversification des cultures: étude au niveau des exploitations agricoles et des filières. $O C L$ 20(4):D403. https://doi.org/10.1051/ ocl $/ 2013007$

Moore, K. M. 2011. Global networks in local agriculture: a framework for negotiation. Journal of Agricultural \& Food Information 12(1):23-39. https://doi.org/10.1080/10496505.2011.539517

Moraine, M., M. Duru, and O. Therond. 2017. A social-ecological framework for analyzing and designing integrated crop-livestock systems from farm to territory levels. Renewable Agriculture and Food Systems 32(1):43-56. https://doi.org/10.1017/S1742170515000526

National Sustainable Agriculture Coalition (NSAC). 2017. Path to the 2018 Farm Bill: crop insurance modernization. NSAC, Washington, D.C., USA.

Naylor, R., H. Steinfeld, W. Falcon, J. Galloway, V. Smil, E. Bradford, J. Alder, and H. Mooney. 2005. Losing the links between livestock and land. Science 310(5754):1621. https://doi. org/10.1126/science. 1117856

Niles, M. T., R. D. Garrett, and D. Walsh. 2018. Ecological and economic benefits of integrating sheep into viticulture production. Agronomy for Sustainable Development 38(1). https:// doi.org/10.1007/s13593-017-0478-y

Obara, K., M. McConnell, and J. Dyck. 2010. Japan's beef market. U.S. Department of Agriculture Economic Research Service, Washington, D.C., USA.

Observatorio ABC. 2016. Analise dos recursos do Programa ABC - Visao Regiona. Fundacao Getulio Vargas, Sao Paulo, Brazil.

O'Donoghue, E. J., M. J. Roberts, and N. Key. 2009. Did the Federal Crop Insurance Reform Act alter farm enterprise 
diversification? Journal of Agricultural Economics 60(1):80-104. https://doi.org/10.1111/j.1477-9552.2008.00166.x

Peyraud, J.-L., M. Taboada, and L. Delaby. 2014. Integrated crop and livestock systems in Western Europe and South America: a review. European Journal of Agronomy 57:31-42. https://doi. org/10.1016/j.eja.2014.02.005

Pigford, A.-A. E., G. M. Hickey, and L. Klerkx. 2018. Beyond agricultural innovation systems? Exploring an agricultural innovation ecosystems approach for niche design and development in sustainability transitions. Agricultural Systems 164:116-121. https://doi.org/10.1016/j.agsy.2018.04.007

Pimentel, D. 2005. Environmental and economic costs of the application of pesticides primarily in the United States. Environment, Development and Sustainability 7:229-252. https:// doi.org/10.1007/s10668-005-7314-2

Pimentel, D., C. Harvey, P. Resosudarmo, K. Sinclair, D. Kurz, M. McNair, S. Crist, L. Shpritz, L. Fitton, R. Saffouri, and R. Blair. 1995. Environmental and economic costs of soil erosion and conservation benefits. Science 267(5201):1117-1123. https:// doi.org/10.1126/science.267.5201.1117

Price, R. J., and R. B. Hacker. 2009. Grain \& Graze: an innovative triple bottom line approach to collaborative and multidisciplinary mixed-farming systems research, development and extension. Animal Production Science 49(10):729-735. https://doi.org/10.1071/ $\underline{\text { EA08306 }}$

Prokopy, L. S., K. Floress, D. Klotthor-Weinkauf, and A. Baumgart-Getz. 2008. Determinants of agricultural best management practice adoption: evidence from the literature. Journal of Soil and Water Conservation 63(5):300-311. https://doi. org/10.2489/jswc.63.5.300

Ruben, R., and J. Pender. 2004. Rural diversity and heterogeneity in less-favoured areas: the quest for policy targeting. Food Policy 29(4):303-320. https://doi.org/10.1016/j.foodpol.2004.07.004

Ryschawy, J., N. Choisis, J. P. Choisis, and A. Gibon. 2013. Paths to last in mixed crop-livestock farming: lessons from an assessment of farm trajectories of change. Animal 7:673-681. https://doi.org/10.1017/S1751731112002091

Ryschawy, J., G. Martin, M. Moraine, M. Duru, and O. Therond. 2017. Designing crop-livestock integration at different levels: toward new agroecological models? Nutrient Cycling in Agroecosystems 108:5-20. https://doi.org/10.1007/s10705-016-9815-9

Ryschawy, J., M. Moraine, M. Pequignot, and G. Martin. 2019. Trade-offs among individual and collective performances related to crop-livestock integration among farms: a case study in southwestern France. Organic Agriculture 9:399-416. https://doi. org/10.1007/s13165-018-0237-7

Schiere, J. B., M. N. M. Ibrahim, and H. Van Keulen. 2002. The role of livestock for sustainability in mixed farming: criteria and scenario studies under varying resource allocation. Agriculture, Ecosystems \& Environment 90(2):139-153. https://doi.org/10.1016/ $\underline{\mathrm{S} 0167-8809(01) 00176-1}$

Sixt, G. N., L. Klerkx, and T. S. Griffin. 2018. Transitions in water harvesting practices in Jordan's rainfed agricultural systems: systemic problems and blocking mechanisms in an emerging technological innovation system. Environmental Science \& Policy 84:235-249. https://doi.org/10.1016/j.envsci.2017.08.010

Smil, V. 1997. Global population and the nitrogen cycle. Scientific American 277(1):76-81. https://doi.org/10.1038/scientificamerican0797-76

Statistics New Zealand. 2012. 2012 agricultural census tables. Statistics New Zealand, Wellington, New Zealand

Stinner, D. H., M. G. Paoletti, and B. R. Stinner. 1989. In search of traditional farm wisdom for a more sustainable agriculture: a study of Amish farming and society. Agricultural Ecology and Environment 27(1-4):77-90. https://doi.org/10.1016/

B978-0-444-88610-1.50010-3

Stuiver, M. 2006. Highlighting the retro side of innovation and its potential for regime change in agriculture. Pages 147-173 in T. Marsden and J. Murdoch, editors. Between the local and the global. Emerald Group, Bingley, UK. https://doi.org/10.1016/S1057-1922 (06)12007-7

Sulc, R. M., and A. J. Franzluebbers. 2014. Exploring integrated crop-livestock systems in different ecoregions of the United States. European Journal of Agronomy 57:21-30. https://doi. org/10.1016/j.eja.2013.10.007

Sulc, R. M., and B. F. Tracy. 2007. Integrated crop-livestock systems in the U.S. corn belt. Agronomy Journal 99:335-345. https://doi.org/10.2134/agronj2006.0086

Therond, O., M. Duru, J. Roger-Estrade, and G. Richard. 2017. A new analytical framework of farming system and agriculture model diversities. A review. Agronomy for Sustainable Development 37(3):21. https://doi.org/10.1007/s13593-017-0429-7

Thigssen, A. G. 2018. Circular agriculture: a new perspective for Dutch agriculture. Wageningen University \& Research, 13 September. [online] URL: https://www.wur.nl/en/newsarticle/ $\underline{\text { Circular-agriculture-a-new-perspective-for-Dutch-agriculture-1.htm }}$

Thornton, P. K., and M. Herrero. 2015. Adapting to climate change in the mixed crop and livestock farming systems in subSaharan Africa. Nature Climate Change 5:830-836. https://doi. org/10.1038/nclimate2754

Thornton, P. K., R. L. Kruska, N. Henninger, P. M. Kristjanson, R. S. Reid, F. Atieno, A. N. Odero, and T. Ndegwa 2002. Mapping poverty and livestock in the developing world. ILRI, Nairobi, Kenya.

Tilman, D., K. G. Cassman, P. A. Matson, R. Naylor, and S. Polasky. 2002. Agricultural sustainability and intensive production practices. Nature 418:671-677. https://doi.org/10.1038/ nature 01014

Tilman, D., J. Fargione, B. Wolff, C. D'Antonio, A. Dobson, R. Howarth, D. Schindler, W. H. Schlesinger, D. Simberloff, and D. Swackhamer. 2001. Forecasting agriculturally driven global environmental change. Science 292(5515):281-284. https://doi. org/10.1126/science.1057544

Tittonell, P., L. Klerkx, F. Baudron, G. F. Félix, A. Ruggia, D. van Apeldoorn, S. Dogliotti, P. Mapfumo, and W. A. H. Rossing. 2016. Ecological intensification: local innovation to address global challenges. Pages 1-34 in E. Lichtfouse, editor. Sustainable agriculture reviews, Volume 19. Springer, Cham, Switzerland. https://doi.org/10.1007/978-3-319-26777-7 1 
Turnheim, B., and F. W. Geels. 2012. Regime destabilisation as the flipside of energy transitions: lessons from the history of the British coal industry (1913-1997). Energy Policy 50:35-49. https:// doi.org/10.1016/j.enpol.2012.04.060

van der Ploeg, J. D. 2010. The peasantries of the twenty-first century: the commoditisation debate revisited. Journal of Peasant Studies 37(1):1-30. https://doi.org/10.1080/03066150903498721

van Zanten, H. H. E., B. G. Meerburg, P. Bikker, M. Herrero, and I. J. M. de Boer. 2016. Opinion paper: The role of livestock in a sustainable diet: a land-use perspective. Animal 10(4):547-549. https://doi.org/10.1017/S1751731115002694

Veysset, P., D. Bébin, and M. Lherm. 2005. Adaptation to Agenda 2000 (CAP reform) and optimisation of the farming system of French suckler cattle farms in the Charolais area: a model-based study. Agricultural Systems 83(2):179-202. https://doi.org/10.1016/ j.agsy.2004.03.006

Vicente, M. 2016. Adoção de ILPF chega a 11,5 milhões de hectares [Adoption of ILPF arrives at 11.5 million hectares]. Embrapa, Brasilia, Brazil.

Vidal, J. 2019. Putting pigs in the shade: the radical farming system banking on trees. The Gaurdian, 13 July. [online] URL: https:// www.theguardian.com/environment/2019/jul/13/pigs-radical-farmingsystem-trees-climate-crisis

Vitousek, P. M., H. A. Mooney, J. Lubchenco, and J. M. Melillo. 1997. Human domination of Earth's ecosystems. Science 277 (5325):494-499. https://doi.org/10.1126/science.277.5325.494

Ward, N. 1993. The agricultural treadmill and the rural environment in the post-productivist era. Sociologia Ruralis 33 (3-4):348-364. https://doi.org/10.1111/j.1467-9523.1993.tb00969. $\underline{\mathrm{x}}$

Warren, D. M. 1994. Indigenous agricultural knowledge, technology, and social change. Pages 35-53 in G. McIsaac and W. R. Edwards, editors. Sustainable agriculture in the American Midwest: lessons from the past, prospects for the future. University of Illinois Press, Urbana, Illinois.

Wigboldus, S., L. Klerkx, C. Leeuwis, M. Schut, S. Muilerman, and H. Jochemsen. 2016. Systemic perspectives on scaling agricultural innovations: a review. Agronomy for Sustainable Development 36:46. https://doi.org/10.1007/s13593-016-0380-z

Yang, H., L. Klerkx, and C. Leeuwis. 2014. Functions and limitations of farmer cooperatives as innovation intermediaries: findings from China. Agricultural Systems 127:115-125. https:// doi.org/10.1016/j.agsy.2014.02.005

Zu Ermgassen, E. K. H. J., B. Phalan, R. E. Green, and A. Balmford. 2016. Reducing the land use of EU pork production: where there's swill, there's a way. Food Policy 58:35-48. https://doi. org/10.1016/j.foodpol.2015.11.001 


\section{Appendix 1}

Table A1.1: Data sources and definitions for Integrated Crop Livestock System (ICLS) estimates

\begin{tabular}{|c|c|c|c|c|}
\hline Country & ICLS definition & ICLS \% calculation & Years available & Source \\
\hline Argentina & $\begin{array}{l}\text { Commercial farms in mixed } \\
\text { production (livestock and agriculture) }\end{array}$ & $\begin{array}{l}\text { As a proportion of all } \\
\text { livestock and agriculture } \\
\text { farms }\end{array}$ & 2013 & $\begin{array}{l}\text { "La Agricultura Familiar en la Argentina } \\
\text { Diferentes Abordajes para su Studio" - } \\
\text { Ministry of Agriculture, Livestock, and } \\
\text { Fishing }\end{array}$ \\
\hline Australia & $\begin{array}{l}\text { Mixed livestock area (farms that } \\
\text { receive }<50 \% \text { of their receipts from a } \\
\text { single enterprise }+ \text { wheat farms that } \\
\text { integrate crops and livestock) }\end{array}$ & $\begin{array}{l}\text { As a proportion of all } \\
\text { non-pastoral area }\end{array}$ & $\begin{array}{l}\text { All years from } \\
1991-2017\end{array}$ & $\begin{array}{l}\text { Australian Bureau of Agricutural and } \\
\text { Resource Economics (ABARE) }\end{array}$ \\
\hline Brazilı & $\begin{array}{l}\text { Area where crops are used to reform } \\
\text { or renovate or recuperate pastures }+ \\
\text { area where animal manure is used on } \\
\text { crop area }\end{array}$ & $\begin{array}{l}\text { As a proportion of all } \\
\text { livestock and crop area }\end{array}$ & 2006 & $\begin{array}{l}\text { Censo Agropecuario - Brazilian Institute of } \\
\text { Geography and Statistics }\end{array}$ \\
\hline \multirow[t]{2}{*}{ Europe 2} & $\begin{array}{l}\text { 1979-1997 \& 2005-2013: Mixed } \\
\text { farming (An agricultural } \\
\text { holding where neither livestock nor } \\
\text { crop production is the dominant } \\
\text { activity; an activity is called } \\
\text { dominant if it provides at least } 2 / 3 \text { of } \\
\text { the production or the business size of } \\
\text { an agricultural holding.) }\end{array}$ & $\begin{array}{l}\text { As a proportion of all } \\
\text { livestock and crop farms } \\
\text { or area }\end{array}$ & $\begin{array}{l}\text { 1975, 1979/1980, } \\
\text { 1985, 1987, } \\
\text { 1989/1990, 1993, } \\
\text { 1995, 1997, 2000, } \\
\text { 2003, 2007, 2010, } \\
2013\end{array}$ & $\begin{array}{l}\text { 1975-1997: Eurostat Farm Structure } \\
\text { Historical Results; 2000: Eurostat Agriculture } \\
\text { Statistical Yearbook Data; } \\
\text { 2007: Eurostat Pocketbooks Agricultural } \\
\text { Statistics Main Results; } \\
\text { 2010: Eurostat Pocketbooks Agriculture, } \\
\text { forestry and fishery statistics; 2013: Eurostat } \\
\text { File: Agricultural holdings, by farm type, by } \\
\text { country }\end{array}$ \\
\hline & $\begin{array}{l}\text { 1999-2003: "field crops-grazing" and } \\
\text { "various crops and livestock } \\
\text { combined" }\end{array}$ & $\begin{array}{l}\text { As a proportion of all } \\
\text { farms }\end{array}$ & 1999/2000, 2003 & $\begin{array}{l}\text { Eurostat Statistics in Focus Structure of } \\
\text { agricultural holdings }\end{array}$ \\
\hline
\end{tabular}




\begin{tabular}{|c|c|c|c|c|}
\hline Japan & $\begin{array}{l}\text { Area of dairy farms which own } \\
\text { cultivated land (crops) + area of } \\
\text { breeding cattle farms which own } \\
\text { cultivated land (crops) }\end{array}$ & $\begin{array}{l}\text { As a proportion of dairy } \\
\text { and breeding cattle farms }\end{array}$ & $\begin{array}{l}2000,2005,2010, \\
2015\end{array}$ & $\begin{array}{l}\text { Census of Agriculture and Forestry - Statistics } \\
\text { of Japan }\end{array}$ \\
\hline \multirow{2}{*}{ New Zealand } & $\begin{array}{l}\text { 1981-1996: Area of cropping with } \\
\text { sheep + area of sheep farming with } \\
\text { cropping }\end{array}$ & $\begin{array}{l}\text { All land: As a proportion } \\
\text { of all grain, sheep, and } \\
\text { beef areas or Non- } \\
\text { pastoral land: As a } \\
\text { proportion of "cropping" } \\
+ \text { cropping with sheep + } \\
\text { sheep farming with } \\
\text { cropping areas }\end{array}$ & $\begin{array}{l}1981,1990,1994 \\
1996,2002\end{array}$ & $\begin{array}{l}\text { Agricultural Production Statistics - Statistics } \\
\text { New Zealand }\end{array}$ \\
\hline & $\begin{array}{l}\text { 2002-2012: Area of grain-sheep } \\
\text { farming + area of grain-beef farming }\end{array}$ & $\begin{array}{l}\text { All land: As a proportion } \\
\text { of all grain growing, } \\
\text { sheep, and beef areas or } \\
\text { Non-pastoral land: As a } \\
\text { proportion of "grain } \\
\text { growing" + grain-sheep } \\
\text { farming + of grain-beef } \\
\text { farming area }\end{array}$ & $2002,2007,2012$ & $\begin{array}{l}\text { Agricultural Production Statistics - Statistics } \\
\text { New Zealand }\end{array}$ \\
\hline Saudia Arabia & 2015: Mixed area/mixed holdings & All & 2015 & Agricultural Census \\
\hline \multirow[b]{2}{*}{ United States } & $\begin{array}{l}\text { 1950-2007: Cropland used only for } \\
\text { pasture or grazing (farms and area) }\end{array}$ & $\begin{array}{l}\text { As a proportion of all } \\
\text { cropland (farms and area) }\end{array}$ & $\begin{array}{l}1950,1954,1959, \\
1964,1969,1974, \\
1978,1982,1987, \\
1992,1997,2002, \\
2007\end{array}$ & $\begin{array}{l}\text { Census of Agriculture - Land Use - US } \\
\text { National Agricultural Statistics Service }\end{array}$ \\
\hline & $\begin{array}{l}\text { 2012: Renamed "other pasture and } \\
\text { grazing land that could have been } \\
\text { used for crops without additional } \\
\text { improvement," but same meaning as } \\
\text { past definition as you can see from } \\
2007 \text { data in table }\end{array}$ & $\begin{array}{l}\text { As a proportion of all } \\
\text { cropland (farms and area) }\end{array}$ & 2012 & $\begin{array}{l}\text { Census of Agriculture - Land Use - US } \\
\text { National Agricultural Statistics Service }\end{array}$ \\
\hline Uruguay & Rice-livestock; livestock over rice & $\begin{array}{l}\text { As a proportion of rice } \\
\text { area + livestock area }\end{array}$ & 1990, 2000, 2011 & Agricultural Statistical Yearbook \\
\hline
\end{tabular}




\section{Appendix 2}

\section{ADDITIONAL INFORMATION ON THE WORKSHOP HELD IN BELÉM - "Understanding barriers to the wide-scale adoption of integrated crop, livestock and forestry systems and potential impacts"}

\section{Goals of the workshop}

In this workshop we sought to better understand barriers to the adoption of integrated systems, the socioeconomic outcomes of adoption, and farmers' perceptions of these systems. Of particular interest were differences in motivations and outcomes between actors and regions, including differences between: i) subsistence and commercial agricultural systems, ii) farmers of different cultural backgrounds and genders, iii) frontier areas and long-established agricultural regions, and iv) national policy contexts. Variations in integration possibilities across different markets and supply chain were another area of interest.

From an academic perspective, the specific objectives of this workshop were to: 1) Share our current understanding of farmers' barriers, motivations, and outcomes related to ICLS across and within regions based on existing work, 2) Assess the generalizability of regional findings, 3) Identify major research gaps, and 4) Develop new ideas for collaborative and comparative work across regions to address research gaps. Based on this meeting and in cooperation with a handful of other researchers that could not attend, we aimed to produce a synthetic paper regarding the theoretical and empirical evidence base for assessing barriers to wide-scale adoption of integrated systems and potential outcomes of wide-scale adoption. From an applied perspective, a primary objective of this workshop is to help facilitate knowledge transfer between the international agricultural social science community and Embrapa to help inform their future research and extension activities related to ICLS.

Early in the course of the workshop it became apparent that a broader focus beyond understanding barriers and motivations to adoption of new versions of ICLS was needed. We thought it was necessary to also examine the reason ICLS were retired in the first place. This was added to the discussions on the second day.

\section{Structure of the workshop}

Days $1 \& 2$ - Optional

- Field trips to Paragominas to see different types of integrated and non-integrated grain and pasture systems in the Brazilian Amazon and talk to farmers about why they adopted/use these systems.

Day 3

- Overview \& Introductions

- Presentations - The challenge of sustainable development in the Brazilian Amazon: What is the role of integrated systems in meeting this challenge? What is Embrapa doing in this area

- Presentations - Farm level integration 
Existing theoretical frameworks for understanding adoption and outcomes of integrated systems given the social and economic contexts in which agricultural systems are embedded. Special attention to: i) motivations and competences in subsistence vs. commercial agricultural systems, ii) heterogeneity in preferences across culture and gender, iii) resources in frontier areas vs. long established agricultural regions, iv) differing incentives provided by national policy structures.

\section{- Presentations - Beyond farm integration and diffusion of integration}

Existing theoretical frameworks for understanding cooperation between farmers to achieve integration of cropping and livestock systems and the role of institutions and innovation systems in promoting change. With specific attention to areas of interest mentioned above, as well as differences in scale, market attributes, and the structure of food chains.

- Small group work $\&$ report out: Are there a common set of theories regarding adoption and diffusion that we can agree on within certain contexts? What theories do we lack?

Day 4

- Recap of Day 3

- Presentations: Empirical results from different regions: Brazil, France, Australia, US, and New Zealand

- Group work \& report out: What are the points of convergence and divergence between regions? What findings are generalizable? Where are the gaps in empirical analysis? -Feel free to draw from other literature.

- Group work \& report out: Developing frameworks to understand trajectories of integrated systems across regions and mapping out the differences between regions.

- Full discussion: Synthesis of insights from the workshop and future directions for research and collaboration to address research gaps

\section{How were participant chosen and expertise of those who were able to attend}

Researchers and practitioners that were known to have written about the socioeconomic and policy dimensions of ICLS based on a literature review were invited. We aimed to have the widest swath of countries with primarily commercial agricultural systems represented, but not all researchers could attend. Attendees had regional expertise on ICLS in Australia, Brazil, China, France, US, New Zealand, Netherlands, and disciplinary expertise in: agroecology, agronomy, economics, geography, innovation studies, and policy analysis, as well as methodological expertise in quantitative and qualitative methods, interviews, experiments, and synthesis. Researchers with expertise on commercial systems in Southeast Asia and Sub-Saharan Africa were invited, but were not able to attend. 


\section{Appendix 3}

\section{ADDITIONAL INFORMATION ON DEFINITIONS OF SUPPORTING AND INHIBITING FACTORS}

\section{Supporting factors (opportunities arising from landscape changes or niche developments)}

a. Cultural preference for autonomy: As a potentially self-sufficient livelihood, farming has long been driven by a desire to pursue an independent lifestyle, free from dependence on markets and governments (Ploeg, 2010). Traditional-ICLS practices enable this self-sufficiency and autonomy by producing all of the necessary inputs to production, as well as a diversity of food sources. While landscape changes and agricultural regime shifts have generally reduced the autonomy of individual farms, certain communities, have withstood pressures to change their systems to prioritize their autonomy due to cultural, religious, and political reasons.

b. Targeted by climate or pollution mitigation policy: Policies that create taxes or fines for carbon, nitrogen, or phosphorus emissions or soil erosion force farmers to internalize the costs of pollution and land degradation to society, incentivizing more environmentally responsible production (Zilberman et al., 1999). Since ICLS tend to promote soil conservation and reduce the carbon and nutrient emissions associated with agricultural production (Balbino et al., 2012; Lemaire and Franzluebbers, 2013), the introduction of taxes or fines on greenhouse gas and nitrate pollution should encourage their adoption vis-à-vis both continuous cropping and animal confinement systems. Conversely, any public policy that pays farmers for the environmental services provided by their farm will have a similar impact on ICLS adoption, albeit by shifting the burden of payment to taxpayers rather than farmers.

c. Highly variable topography, climate, or soil: Soil and water constraints can limit crop and forage production. This works to incentivize ICLS from two directions: livestock farmers seek out additional grazing areas (e.g., on neighboring farms) to supplement their livestock (i.e., rows between grape vines, stubble of cover and forage crops), while would-be crop farmers raise livestock in areas with topographical and soil features that are not suitable for cropping (Lacoste et al., 2018).

d. Creation of agricultural research and development programs focused on sustainability and climate adaptation: Federally supported research and extension directly focused on ICLS can help incentivize the adoption of these management systems (FAO, 2010). Long term agronomic and animal health research can help improve the production, animal welfare, and environmental outcomes of these systems (FAO, 2010), while economic research can help identify which systems are most efficient.

e. Industry and civil society initiatives promoting ICLS: ICLS is often implicitly promoted by permaculture, organic, and biodynamic civil society networks (Allen et al., 2005; Cunfer, 2004; Faust et al., 2017; Lovell et al., 2010). An additional stimulus for new-ICLS adoption comes from the rise of peasant movements calling for self-sufficiency and autonomy in reaction to globalization, such as La Via Campesina and Fédération Associative pour le Développement de l'Emploi Agricole et Rural (FEDEAR) (Dumont et al., 2016). In seeking self-sufficiency for cost-savings and autonomy, these social movements often promote more holistic and agro-ecological farm-management approaches that reduce reliance on external inputs, including types of new-ICLS (Bonaudo et al., 2014; Dumont et al., 2016). 
f. Differentiated value chains and eco- or social labels: The possibility to market ICLS products as "local" and "green", leading to the creation of a differentiated market in crop and livestock value chains could help incentivize adoption in regions where consumers already have strong environment or local food preferences.

\section{Inhibiting factors (barriers arising from the agricultural regime or a lack of niche developments needed to push changes)}

a. Lack of supply chain infrastructure or marketing opportunities: ICLS require a diverse union of supply chain infrastructure that enable access to markets for multiple products (Gil et al., 2016). In some agricultural regions, where economies of scale have favored the specialization of agribusiness around a single product, there may be limited supply chain infrastructure or marketing channels for diverse products (Garrett et al., 2013a, 2013b).

b. High labor prices: Livestock production tends to be more labor intensive than cropping (at least specialized, mechanized cropping) and most forms of crop-livestock integration require greater management attention (Bell and Moore, 2012).

c. Low prices of synthetic inputs and fuel or feed: The lower the prices for synthetic inputs and fuel or feed, the fewer incentives farmers have to produce these products on their own farm via ICLS (Garrett et al., 2017b).

d. Protectionist policies (e.g., insurance, subsidies): As a more diversified form of production vis-à-vis continuous crop monocultures or single animal systems, ICLS can be an important mechanism for reducing farmers' risk (Bowman and Zilberman, 2011; O'Donoghue et al., 2009). Therefore, policies that protect policies via price subsidies, minimum price floors, or subsidized insurance on margin or production losses will also reduce incentives for ICLS and encourage specialization.

e. Food safety regulations restricting integration: Policies that create restrictions and fines regarding the presence of animals or animal excrement in cropland areas will disincentivize many forms of ICLS (Garrett et al., 2017b). The impact of these food safety restrictions will depend on the types of crops they apply to (typically non-food crops and crops that are processed or intended for home consumption are excluded) and the minimum exclusion time between animal grazing or manure application and planting.

f. Lack of ICLS farm trials/demonstration: Demonstration farms, farm trials, and extension programs can help spread information about the potential benefits of ICLS and technical details about how to operate such systems (Gil et al., 2016). In regions where these don't exist farmers may not have sufficient information about how to adopt ICLS.

g. Lack of farmer networks to share knowledge on ICLS: Farmers' networks have proved to be influential on perceptions of specific technologies (Lubell et al., 2014; Prokopy et al., 2008). Creation of multi-actor and cross-sectoral groups can be a further step in supporting ICLS (Pigford et al., 2018), especially when these groups are supported by participatory scenario building (Ryschawy et al., 2017). 


\title{
ADDITIONAL INFORMATION ON RANKINGS OF SUPPORTING AND INHIBITING FACTORS
}

We used a combination of our expert knowledge and additional literature review of each case to develop the qualitative rankings that are presented below (and summarized in Table 1).

\section{Traditional-ICLS persistence}

\section{a. Amish farms in United States}

\author{
Supporting factor - Cultural preference for autonomy - Very high \\ Supporting factor - Industry or civil society networks promoting ICLS - High \\ Inhibiting factor - Lack of ICLS farm trials/demonstration - Low \\ Inhibiting factor - Lack of farmers' knowledge networks on ICLS - Low
}

The religious/cultural beliefs of Amish farming groups include controls on new technologies that would threaten their Christian values (Brock and Barham, 2015). For some orders this includes an avoidance of modern technology (e.g., synthetic inputs, heavy machinery) and a refusal of government assistance, such as subsidized insurance (Stinner et al., 1989). Amish tradition encourages "The purposeful stability of cultural practices and ideas with controlled introductions of new forms," (Parker, 2013). These traditions helped lock-in traditional-ICLS as a preferred model of farming. Given that most Old Order Amish farmers are surrounded by other farmers pursuing the same practices, there is no shortage of successful demonstration farms.

\author{
Supporting factor - Targeted by climate or pollution mitigation policy - Low \\ Supporting factor - Creation of agricultural R\&D programs focused on sustainability and climate adaptation - Low \\ Inhibiting factor - Low prices of synthetic inputs and fuel - Low \\ Inhibiting factor - Protectionist policies (e.g., insurance, subsidies) - Low
}

Old Order Amish farmers tend to be influenced more by tradition and their cultural model of good stewardship, rather than external policies and research or market prices (Parker, 2013). The emphasis on autonomy and control over ideas is associated with a rejection of government interference/support. Since religious views explicitly prohibit the use of synthetic inputs, the overall low prices of these inputs in the US would not play a large role in the broader choice to pursue ICLS.

\section{Inhibiting factor - Food safety regulations restricting integration - Moderate}

The Food Safety Modernization Act of 2011 provides standards for the safe production and harvesting of food crops. This Act has the potential to impact certain forms of ICLS adoption through rules limiting the presence of animals and use of animal excrement on cropland. While these regulations provide potential benefits for public health, they could discourage the integration of animals into cropping systems. Yet, foods destined for home consumption and foods that will be processed before consumption are exempt from the policy. This limits their impact on Amish farming systems. 


\section{Supporting factor - Highly variable topography, climate, or soil - Moderate}

Ohio has the largest Amish settlement in the world and a majority of this group reside in Sugar Creek, Ohio (Parker et al., 2009). This region is characterized by a high degree of variability in topography, geology and soil, and ecosystems. Yet, this variability is not necessarily high within individual farms, and given the cultural considerations above, not the major driver of ICLS persistence.

\section{Supporting factor - Differentiated value chains and eco- or social labels - Moderate}

Inhibiting factor - Lack of supply chain infrastructure or marketing opportunities - Moderate

Amish farmers have found a strong and stable niche in marketing their products via organic dairies, either via cooperatives or directly trading to individual cheese brands (Brock and Barham, 2015).

\section{High cost of labor - Low}

Traditional Old Order Amish discontinue education after primary school as labor is directed at the farming unit. Furthermore, labor is fairly abundant (Parker et al., 2009) - population growth in Amish communities has led to high increased migration out of existing regions.

\section{b. Family farms (smallholders*) in Brazil}

*In Brazil family farms are defined as farms under a certain size that primarily rely on household labor.

\section{Supporting factor - Cultural preference for autonomy - Moderate}

Generally speaking, small "peasant" farmers are thought to have a high preference for autonomy (Ploeg, 2010). Yet smallholder autonomy in Brazil has also developed out of a "lack of options". That is farmers cannot necessarily rely on the government for support and have to be self-sufficient.

\section{Supporting factor - Targeted by climate or pollution mitigation policy - Moderate}

Brazil implemented many aggressive climate change policies in Brazil during the 2000s (see "Pastures and Croplands in Brazil"). However, in practice, family farmers are much less targeted by these policies than large farmers.

\section{Supporting factor - Highly variable topography, climate, or soil - Moderate}


Even small farms in Brazil can be fairly large (depending on the region), so there can be large variety of soil types within a single geography. However, outside of the mountainous regions in Minas Gerais there is not normally substantial variation in topography within single farms.

\section{Supporting factor - Creation of agricultural R\&D programs focused on sustainability and climate adaptation - Low \\ Supporting factor - Industry or civil society networks promoting ICLS - Low \\ Inhibiting factor - Lack of ICLS farm trials/demonstration - Moderate \\ Inhibiting factor - Lack of farmers' knowledge networks on ICLS - Low}

Despite large R\&D efforts for new-ICLS adoption in Brazil, including cooperation with agribusinesses to support new-ICLS technologies (see "Pastures and Croplands in Brazil"), federal research and extension programs often fail to reach small and medium farmers (Cortner et al., 2019). Additionally smallholders are not likely to interact with major agribusinesses (Garrett et al., 2017a). Nevertheless, traditional forms of ICLS have persisted and are socially embedded, so there is general community knowledge about how to pursue these types of systems.

\section{Supporting factor - Differentiated value chains and eco- or social labels - Low \\ Inhibiting factor - Lack of supply chain infrastructure or marketing opportunities - High \\ Inhibiting factor - Low prices of synthetic inputs and fuel - Low}

Many agricultural regions have limited agribusiness infrastructure (Garrett et al., 2013b), which constrain farmers' ability to adopt newer forms of ICLS (Gil et al., 2016). Because of these infrastructure limitations, the prices of synthetic inputs are higher in more remote regions where smallholders typically reside. Additionally, these inputs tend to be financially out of reach for smallholders who have little cash or credit available. There are very few channels for marketing higher value crops or niche products that could support smallholders in leveraging their traditional-ICLS systems toward differentiated value chains (Garrett et al., 2017a).

\section{Inhibiting factor - High cost of labor - Low}

As mentioned above, in Brazil family farms are defined as farms under a certain size that primarily household labor. Thus, relative to their size, labor tends to be abundant and low cost (since off-farm job opportunities are low) (Garrett et al., 2017a).

\section{Inhibiting factor - Protectionist policies (e.g., insurance, subsidies) - Low}

Family farmers are required to purchase coverage through the Insurance for Family Farmers (SEAF) program when they access subsidized loans through the Program for Strengthening Family Agriculture. However, currently this program reaches less than $1 \%$ of farmers (Canal do Produtor, 2012; IBGE, 2006).

\section{Inhibiting factor - Food safety regulations restricting integration - Low}

Food safety laws in Brazil are geared toward processing facilities and complying with the sanitary and phytosanitary regulations of importing countries (Salay and Caswell, 1998). Brazil does not have restrictions on the use of animal grazing or manure in food crop areas (Garrett et al., 2017b). 


\section{New-ICLS reemergence}

\section{a. Pastures and croplands in Brazil}

\section{Supporting factor - Cultural preference for autonomy - Moderate}

Farmers in Brazil tend to be open to government support in the sense that they receive substantial subsidies via low interest loans and are willing to engage in complex agribusiness markets (Garrett et al., 2013b). However, many farmers are averse to government interventions that constrain their behaviors or encourage them to adopt more pro-environmental behaviors (Cortner et al., 2019).

\section{Supporting factor - Targeted by climate or pollution mitigation policy - High}

In Brazil, new-ICLS is being promoted by the government's Low Carbon Agriculture (ABC) Plan and increasing restrictions on native vegetation clearing that are linked to Brazil's broader international commitment to reduce national greenhouse gas emissions (Gil et al., 2016). The ABC program provides subsidized loans for adoption of integrated systems to combat soil degradation and recuperate pastures through the introduction of crop species, thereby shortening the cattle life cycle and reducing emissions per unit of food produced (Observatorio ABC, 2016). Restrictions on forest clearing have incentivized the adoption of ICLS to increase productivity on the existing land area (Cortner et al., 2019; Garrett et al., 2018).

\section{Supporting factor - Highly variable topography, climate, or soil - Moderate}

There is a large variety of soil types within a single farm. However, outside of the mountainous regions in Brazil there is not substantial variation in topography in the major agricultural regions.

\section{Supporting factor - Creation of agricultural R\&D programs focused on sustainability and climate adaptation - High Supporting factor - Industry or civil society networks promoting ICLS - Moderate Inhibiting factor - Lack of ICLS farm trials/demonstration - Moderate Inhibiting factor - Lack of farmers' knowledge networks on ICLS - Moderate}

Since the 1980s, the Brazilian Agricultural Research Corporation (Embrapa) has been doing research on ICLS in beef cattle systems as a mechanism to restore degraded pastures. In the early 1990s, six existing Embrapa state research units in the North region were transformed in Agroforestry Research Centers. This restructuring process strengthened R\&D on agroforestry and integrated crop, livestock, and forestry systems in deforested areas (Flores, 1991). Federal research on ICLS increased substantially during the 2000s and resulted in the development of ICLS farm trials and demonstration site (Embrapa, 2016). Recent research has shown that ICLS adoption is significantly higher near these 
sites (Gil et al., 2016). These efforts have included cooperation with agribusinesses to support new-ICLS technologies (i.e., the "Rede-ILPF" [ICLS-Network], https://www.embrapa.br/web/rede-ilpf/rede-ilpf ). Yet, the engagement of retailers is only starting and few farmer associations have ICLS on their agenda. In a study of ICLS adopters and non-adopters the Brazilian Amazon, most adopters had high awareness of the technical aspects and benefits of ICLS, and were well connected to social groups supporting these systems. Yet, non-adopters were less well connected and cited a lack of information as one barrier to adoption (Cortner et al., 2019).

\section{Inhibiting factor - Lack of supply chain infrastructure or marketing opportunities - High}

Inhibiting factor - Low prices of synthetic inputs and fuel - Moderate

Many agricultural regions have limited agribusiness infrastructure (Garrett et al., 2013b), which constrains farmers' ability to adopt newer forms of ICLS (Gil et al., 2016). Because of these infrastructure limitations, the prices of synthetic inputs in Brazil are higher in more remote regions.

\section{Supporting factor - Differentiated value chains and eco- or social labels - Low}

There are very few channels for marketing higher value crops or niche products (Garrett et al., 2017a). One exception is the higher meat grading for cattle that have higher fat content, which can be linked to ICLS (Cortner et al., 2019).

\section{Inhibiting factor - High cost of labor - Moderate}

While wages are not as high as developed countries, they are increasing and labor trained to work with machinery or advanced livestock management tends to be scarce. Farmers' perceive skilled labor scarcity as a major barrier to adopting ICLS (Cortner et al., 2019).

\section{Inhibiting factor - Protectionist policies (e.g., insurance, subsidies) - Low}

In 2011, all public and private mechanisms for mitigating risks in agriculture were accessed by 1.55 million farmers, covering $18 \%$ of the agricultural area in Brazil (MBAgro, 2012).

\section{Inhibiting factor - Food safety regulations restricting integration - Low}

Food safety laws in Brazil are geared toward processing facilities and complying with the sanitary and phytosanitary regulations of importing countries (Salay and Caswell, 1998). Brazil does not have restrictions on the use of animal grazing or manure in food crop areas (Garrett et al., 2017b).

\section{b. Non-Pastoral areas in Australia}

\section{Supporting factor - Cultural preference for autonomy - High}


The concept of autonomy is more commonly expressed as "self-reliance" in the Australian literature and is highly valued as an objective of farming (Waters et al., 2009). Indeed, much of the agricultural policy is built around the concept of farmer self-reliance - that is, policy interventions should not create dependency, but rather leave farmers in charge of their own destiny (Kiem, 2013).

\section{Supporting factor - Targeted by climate or pollution mitigation policy - Moderate}

In 2011 Australia passed the Carbon Credits Act (C2017C00076). This policy provides carbon credits to farmers and land managers through eligible carbon abatement activities which store or reduce greenhouse gas (GHG) emissions on land. This could include ICLS practices.

\section{Supporting factor - Highly variable topography, climate, or soil - High}

In Australia farms are very large. Landscape heterogeneity has been a major impetus for adoption of new-ICLS (Bell and Moore, 2012), leading to the incorporation of livestock areas to take advantage of topographical and soil features that are not suitable for cropping (Lacoste et al., 2018).

\section{Supporting factor - Creation of agricultural R\&D programs focused on sustainability and climate adaptation - High Supporting factor - Industry or civil society networks promoting ICLS - Moderate Inhibiting factor - Lack of ICLS farm trials/demonstration - Moderate Inhibiting factor - Lack of farmers' knowledge networks on ICLS - Moderate}

The Grain and Graze program aimed to increase integration of beef and sheep with crop production by improving the profits, reducing environmental impacts, and building social capital in ICLS via the adoption of best management practices (Price and Hacker, 2009). A major objective was to improve "whole-farm knowledge" and promote researcher-to-farmer knowledge networks via annual research and extension forums (Hacker et al., 2009). The program is credited with the adoption of new-ICLS practices by 3200 farmers over five years despite unfavorable climatic conditions (Price and Hacker, 2009). Nevertheless, knowledge gaps and extension remain an important challenge for scaling up ICLS (Price, 2009).

\section{Supporting factor - Differentiated value chains and eco- or social labels - Low}

The development of value chains for more sustainable food products has been slow to take off in Australia due to consumer skepticism (Bhaskaran et al., 2006). While international markets for sustainable product are growing, most of the beef exported from Australia is still sent to commodity markets that differentiate only on meat grade (Lawrence, 2002).

\section{Inhibiting factor - Lack of supply chain infrastructure or marketing opportunities - Moderate}

Most of the grains produced via ICLS are intended to overcome seasonal forage production shortfalls and are consumed locally rather than marketed (Hacker et al., 2009). Further development of cropping systems could be constrained by limited infrastructure.

Inhibiting factor - Low prices of synthetic inputs and fuel - High 
Low and declining input prices have favored cropping over ICLS systems in Australia (Bell and Moore, 2012).

\section{Inhibiting factor - High cost of labor - High}

Studies of Australian farms have shown that labor costs for integrated systems are significantly higher than specialized cropping systems and a likely factor inhibiting adoption/encouraging retirement of new-ICLS (Bell and Moore, 2012).

\section{Inhibiting factor - Protectionist policies (e.g., insurance, subsidies) - Low}

Australia dismantled most supports for farmers in the 1970s. Most industries receive little assistance and it is mainly in the form of adjustment assistance, R\&D support, drought relief and tax concessions (Productivity Commission, 2005).

\section{Inhibiting factor - Food safety regulations restricting integration - Low}

None of Australia's food safety policies prohibit the presence or use of animals or manure on cropland area.

\section{c. Non-Pastoral areas in New Zealand}

\section{Supporting factor - Cultural preference for autonomy - High}

In a 2002 survey $88 \%$ of New Zealand dairy farmers stated autonomy or "being one's own boss" was their primary motivation for farming (Pangborn, 2009). Additionally, the economic reforms in the 1970s have nearly completely deregulated farming, leaving them as economic entrepreneurs (Stock and Forney, 2014).

\section{Supporting factor - Targeted by climate or pollution mitigation policy - Moderate}

The Resource Management Act (RMA) of 1991 (Public law No 69) stipulates that the use of land must be consistent with "national environmental standards, regional rules, or district rules". The RMA and other environmental regulations are administered by Regional Councils, who are tasked with issuing permits for resource consents (activities that may influence environmental quality, including agriculture). The 2014 National Policy Statement for Freshwater Management reinforces the responsibilities of regional councils for dealing with these issues, clarifying their responsibility under the RMA for decision-making and management planning. The policy statement emphasizes responsible use of water resources with respect to climate change, prohibits the over-allocation of water, and charges Regional Councils with mitigating adverse effects. The most significant aspect of the regulation was to establish a minimal acceptable condition for freshwater across a variety of contaminant parameters. Regional Councils with particularly acute water quality issues have already or are currently implementing regional policies related to nitrogen management through cap and trade programs.

\section{Supporting factor - Highly variable topography, climate, or soil - Moderate-High}


Given the rolling topography of many of the agricultural regions, there is substantial variation in climate and soils in New Zealand farming systems. Soil and water constraints limit forage production, creating incentives for beef and sheep farmers to seek out additional grazing areas to supplement their livestock (i.e., rows between grape vines, stubble of cover and forage crops). In some regions, however, this variation serves as a barrier for ICLS because the soil type and water accessibility are insufficient for cropping systems (Garrett et al., 2017b; Minneé et al., 2009).

\section{Supporting factor - Creation of agricultural R\&D programs focused on sustainability and climate adaptation - Moderate Supporting factor - Industry or civil society networks promoting ICLS - Moderate \\ Inhibiting factor - Lack of ICLS farm trials/demonstration - High \\ Inhibiting factor - Lack of farmers' knowledge networks on ICLS - Low}

There is some focus within New Zealand Crown Research Institutes (CRIs), to conduct research on ICLS. Plant and Food work on integrating sheep into vineyards, while AgResearch works on crop, forage, pasture, and sheep/beef and dairy integration. The New Zealand Agriculture Greenhouse Gas Research Center pursues a research agenda of reducing greenhouse gas emissions across sectors by partnering with the industry group DairyNZ and the CRI AgResearch to conduct analysis of integrated systems (NZAGRC, 2016). The Sustainable Farming Fund invests up to $\$ 8$ million per year in research and extension programs led directly by farmers to fill gaps in industry-funded research by opening a grass-roots award mechanism focused on sustainability to farmers. Several of the funded projects in SFF's portfolio are explicitly directed toward integration (MPI, 2015). Despite all this funding there are still few ICLS specific farm trails.

\section{Supporting factor - Differentiated value chains and eco- or social labels - Moderate Inhibiting factor - Lack of supply chain infrastructure or marketing opportunities - Low}

Due to the small size of New Zealand and the presence of both crop and livestock farming throughout all major production regions, supply chain infrastructure for marketing conventional ICLS products is not a major issue. However, given the small population size and large distance to international markets, reaching differentiated markets can be somewhat of a challenge. Still, grass-fed lamb labels and integrated sheepviticulture systems have made their way onto labels and differentiated markets (Niles et al., 2018). More generally New Zealand has been working on branding its wine in terms of environmental sustainability.

\section{Inhibiting factor - Low prices of synthetic inputs and fuel - Moderate}

New Zealand has no tariff on fertilizer imports and a 5\% tariff on imported animal feeds (New Zealand Ministry for Foreign Affairs and Trade (MFAT), 2012). However, five separate biosecurity acts and standards regulate the import of animal feeds, including the Import Health Standard, Animal Products Act (1999), Agricultural Compounds and Veterinary Medicines Act (2011), Biosecurity (Ruminant Protein) Regulations (1999), and the Biosecurity Act (1993). These acts make it relatively expensive to import feed or feed components (New Zealand Government, 2015). Fonterra, the largest dairy company in the world, and virtual monopoly in New Zealand, encouraged farmers to keep palm kernel rations (an imported feed source) at $3 \mathrm{~kg}$ per animal per day in 2015 (Fonterra, 2015). Nevertheless, fertilizer and feed imports (particularly for dairy) are high in New Zealand and have continued to increase since policy reforms in the 1980s (MacLeod and Moller, 2006). 


\section{Inhibiting factor - High cost of labor - High}

Labor is frequently mentioned as a limiting factor for New Zealand agriculture, as they rely heavily on seasonal migration for labor intensive agricultural industries. Labor savings are cited as one of the major benefits of adopting ICLS (Niles et al., 2018).

\section{Inhibiting factor - Protectionist policies (e.g., insurance, subsidies) - Low}

Farmers in New Zealand receive no support through minimum prices or direct payments (MacLeod and Moller, 2006) - all agricultural subsidies were removed in 1984. As a result, New Zealand has the lowest support for agriculture of any OECD country (producer supports are estimated at $0.7 \%$ of gross farm receipts) (Organisation for Economic Development (OECD), 2016). Crop insurance in New Zealand is voluntary and unsubsidized. These factors require farmers to manage their own risks, often by diversifying production (Evans et al., 1996).

\section{Inhibiting factor - Food safety regulations restricting integration - Low}

None of New Zealand's Food Safety acts prohibit the presence or use of animals or manure on cropland area (Ministry for Primary Industries, 2016)

\section{d. Agroecological farms in France}

\section{Supporting factor - Cultural preference for autonomy - High}

Recent studies have highlighted the autonomy as a major motivation for ICLS in France, especially limiting reliance on external markets for crop inputs and livestock feed (Coquil et al., 2014; Ryschawy et al., 2013). This autonomy is not necessarily limited to the farm level, but also may be supported via territorial synergies, e.g. exchanges within groups of 10-15 neighboring farmers (Moraine et al., 2017; Ryschawy et al., 2017).

\section{Supporting factor - Targeted by climate or pollution mitigation policy - High}

ICLS and other forms of agro-ecological farming systems have been promoted via the Agro-ecological Plan launched in 2012 by the French Ministry of agriculture. A specific program called 4/1000 was implemented to encourage carbon storage in soils through agroecological practices (4/1000 pertains to a target of growing soil carbon by $0.4 \%$ per year). Self-sufficiency and in particular ICLS were particularly encouraged at farm or collective levels through this policy and through the European Commission. At the collective level, funding was given to groups of farmers engaged in agro-ecological activities, including territorial-ICLS (alim'agri, 2017)

\section{Supporting factor - Highly variable topography, climate, or soil - Moderate}

In France traditional-ICLS and new-ICLS tend to occur in less-favored areas where crops cannot be grown (e.g., steep slopes or wetlands), or where cropping is less profitable (Ryschawy et al., 2013; Schiere et al., 2002).

\section{Supporting factor - Creation of agricultural R\&D programs focused on sustainability and climate adaptation - Moderate}


The European Commission has launched a European Innovation Partnership (EIP) Focus Group of experts to build state of the art ICLS (EIPAGRI, 2017). Operational Groups have been funding field projects across Europe where research, advising, marketing and farmers are brought together to develop agro-ecological forms of ICLS and new skills for farmers (EIP-AGRI, 2017).

\section{Supporting factor - Industry or civil society networks promoting ICLS - Low}

Most industry marketing channels remain highly focused on either the crop or livestock sector independently (EIP-AGRI, 2017). Civil society is generally not informed of the challenges of ICLS and more concerned by animal welfare, quality labels or local food chains (Dumont et al., 2016).

\section{Supporting factor - Differentiated value chains and eco- or social labels - Moderate}

In specific areas, there are well-established quality-label products ensuring remuneration to farmers for products based on locally-sourced feeds, good image, and contributions to territorial vitality, but those are mostly linked to livestock products and not ICLS specifically (Beudou et al., 2017). The recent consumer interest in decreasing food waste could be seen as an opportunity for ICLS (Dumont et al., 2016).

\section{Inhibiting factor - Lack of supply chain infrastructure or marketing opportunities - High}

Agglomeration economies have favored the regional concentration of supply chain infrastructure for certain crops or livestock (Gaigne, 2012). In general, there is a lack of marketing options for livestock by-products (wool, manure, ...).

\section{Inhibiting factor - Low prices of synthetic inputs and fuel - High \\ Inhibiting factor - High cost of labor - High}

The labor supply available in agriculture across Europe has shrunk over recent decades and there has also been a loss of skills and motivation to manage both crops and livestock (Peyraud et al., 2014). In France, the large decrease of ICLS has been linked explicitly to the lack of workforce to manage both crop and livestock and the high cost of labor relative to input and fuel costs (Ryschawy et al., 2013; Veysset et al., 2005)

\section{Inhibiting factor - Protectionist policies (e.g., insurance, subsidies) - High}

Livestock has suffered from strong competition with crops as a result of protectionist policies. Since 1970 the 1st pillar of CAP has provided high subsidies for crops, which has led to a general process of specialization and modernization of local agriculture (Veysset et al., 2005).

\section{Inhibiting factor - Food safety regulations restricting integration - Moderate}

Food safety regulations are not limiting ICLS at the farm level directly, but they are limiting the recycling of waste between farms for animal feed or manure use (Dumont et al., 2018). Specific regulations around direct sales of products between farmers are limiting the development of ICLS beyond farm level in France (Ryschawy et al., 2018). 


\section{Inhibiting factor - Lack of ICLS farm trials/demonstration - High}

Research and advising have been mostly focused on either crop or livestock management (EIP-AGRI, 2017). There are few examples of farm demonstrations for ICLS. At INRA (French National Institute for Research in Agronomy), only three demonstration farms are considering ICLS. In general, advising systems are implementing trials on specific crops and not considering the effects of crop-livestock integration.

\section{Inhibiting factor - Lack of farmers' knowledge networks on ICLS - Moderate}

A lack of farmers' skills to manage ICLS has been underlined by the EIP Focus Group around ICLS (EIP-AGRI, 2017). Still, some farmers' knowledge networks that were not focusing on ICLS are now considering these systems in their discussions, such as groups around conservation agriculture or livestock feed autonomy through pasture use

\section{e. Carbon farming in the United States}

\section{Supporting factor - Cultural preference for autonomy - High}

The value of autonomy in American agriculture is linked to Jeffersonian agrarian values and the concept "rugged individualism" (Sullivan et al., 1996). In a survey of both conventional and organic crop farmers in the US, independence was listed as the major benefit of being a farmer (whereas low financial return was listed as the biggest drawback) (Sullivan et al., 1996). Even in the hog industry, independence has been shown to be an important driver of behavior - farmers will avoid contractual arrangements that could reduce risk to maintain autonomy (Key, 2005).

\section{Inhibiting factor - Protectionist policies (e.g., insurance, subsidies) - High}

Farmers receive very high levels of support, though the type of support they receive has shifted substantially over time from price supports to income supports based on current production (after 1965), to income supports based on historical production (after 1990), to insurance for yield and revenue losses (after 2014) (Dimitri et al., 2005; Garrett et al., 2017b). Uptake of insurance programs is fairly widespread (Farrin et al., 2016; USDA, 2013). In areas where there are no available crop insurance options, the Noninsured Crop Assistance Program provides coverage for losses due to weather.

\section{Supporting factor - Targeted by climate or pollution mitigation policy - Moderate}

The Clean Water Act aims to mitigate the pollution of water through the approval of discharge permits (33 U.S.C. §1251; 1972), many of which are required of Confined Animal Feeding Operations (CAFOs) if they propose to discharge to water. The Safe Drinking Water Act protects underground sources of drinking water by regulating how farms handle both liquid waste and wastewater and requires regular sampling of drinking water to identify microbial contamination (42 U.S.C. §300f; 1974). However, farmers are often provided with exemptions to these rules 
and violations are rarely enforced (Dowd et al., 2008). Since 1990 the US Farm Bill has included additional environmental considerations, including the Environmental Benefits Index (EBI), which helps prioritize land for conservation across multiple environmental attributes, and the Environmental Quality Incentives Program (EQIP), which provides financial and technical assistance for investments in environmental protection. The 2014 Farm Bill's Conservation Stewardship Program (CSP) and EQIP both provide payments to farmers for several ICLS related behaviors such as not burning crop residue, intensive rotational grazing, transition to organic cropping systems, and nutrient and feed management. There is currently no climate policy addressing agriculture.

\section{Supporting factor - Highly variable topography, climate, or soil - Low}

We consider biophysical and climate variability to be of low importance since to date it is not mentioned in any of the US literature as a motivation for ICLS adoption.

\section{Supporting factor - Creation of agricultural R\&D programs focused on sustainability and climate adaptation - Moderate Inhibiting factor - Lack of ICLS farm trials/demonstration - High Inhibiting factor - Lack of farmers' knowledge networks on ICLS - High}

Agricultural research is mainly supported through the Farm Bill and the National Institute of Food and Agriculture (NIFA). NIFA funds several programs that are salient to ICLS, including programs on sustainable agriculture, organic agriculture, soil health, manure and nutrient management, and risk management education (NIFA, 2016). Recently NIFA has developed several grant programs that support research on ICLS (NIFA, 2015; USDA, 2015). Nevertheless, allocations to ICLS comprise only 15\% of the $\$ 135$ million in agricultural research funding that is provided by the 2014 Farm Bill per year (NIFA, 2015; USDA, 2015). Farm trials and demonstrations are rare, but do occur at some NIFA-funded Land Grant colleges (see Garrett et al., 2017b for specifics).

\section{Supporting factor - Industry or civil society networks promoting ICLS - Moderate}

In the US ICLS has been promoted via permaculture, organic, and biodynamic civil society networks, e.g. "Soil Carbon Cowboys" (Allen et al., 2005; Cunfer, 2004; Faust et al., 2017; Lovell et al., 2010).

\section{Supporting factor - Differentiated value chains and eco- or social labels - High}

Consumer markets for local and sustainable products (e.g., high end retailers, farmers markets, etc.) have grown substantially in recent decades (Dimitri and Greene, 2000). Besides differentiation via organic and biodynamic labels, more specific marketing opportunities have been identified for grass-fed livestock (Gwin, 2009) and integrated sheep-viticulture (Ryschawy et al., In Review).

\section{Inhibiting factor - Lack of supply chain infrastructure or marketing opportunities - Moderate}

Limited meat processing infrastructure, specifically for small livestock, has been noted as a challenge for ICLS in the US (Hilimire, 2011).

\section{Inhibiting factor - Low prices of synthetic inputs and fuel - High}




\section{Inhibiting factor - High cost of labor - Moderate}

Low prices of fertilizers and fuel explain structural changes in US agriculture, including less diversification (Dimitri et al., 2005).

Specialization in the US has also been fostered via mechanization, which helped reduce the costs of labor (Sulc and Tracy, 2007). Nevertheless, the US has greater abundance to cheap agricultural labor relative to many other regions due to seasonal migration from Mexico.

\section{Inhibiting factor - Food safety regulations restricting integration - High}

The Food Safety Modernization Act of 2011 provides standards for the safe production and harvesting of food crops and has the potential to impact certain forms of ICLS adoption through rules related to the presence of animals and use of animal excrement on cropland that produces food for human consumption. While these regulations provide potential benefits for public health, they could discourage the integration of animals into non-organic food crops and tree fruit systems. Foods destined for home consumption are exempt from the policy. 


\section{References:}

Alim'agri, 2017. Plus de 400 GIEE qui s'engagent dans l'agro-écologie.

Allen, V.G., Brown, C.P., Kellison, R., Segarra, E., Wheeler, T., Dotray, P.A., Conkwright, J.C., Grenn, C.J., Acosta-Martinez, V., 2005. Integrating cotton and beef production to reduce water withdrawal from the Ogallala aquifer in the southern High Plains. Agronomy Journal 97. https://doi.org/10.2134/agronj2005.0556

Balbino, L.C., Cordeiro, L.A.M., Oliveira, P. de, Kluthcouski, J., Galerani, P.R., Vilela, L., 2012. Sustainable agriculture through integrated croplivestock-forestry system. Informacoes Agronomicas 3-14.

Bell, L.W., Moore, A.D., 2012. Integrated crop-livestock systems in Australian agriculture: Trends, drivers and implications. Agricultural Systems $111,1-12$.

Beudou, J., Martin, G., Ryschawy, J., 2017. Cultural and territorial vitality services play a key role in livestock agroecological transition in France. Agronomy for Sustainable Development 37, 36.

Bhaskaran, S., Polonsky, M., Cary, J., Fernandez, S., 2006. Environmentally sustainable food production and marketing: opportunity or hype? British food journal 108, 677-690.

Bonaudo, T., Bendahan, A.B., Sabatier, R., Ryschawy, J., Bellon, S., Leger, F., Magda, D., Tichit, M., 2014. Agroecological principles for the redesign of integrated crop-livestock systems. European Journal of Agronomy 57, 43-51. https://doi.org/10.1016/j.eja.2013.09.010

Bowman, M., Zilberman, D., 2011. Economic factors affecting diversified farming systems. Ecology and Society 18, 33.

Brock, C., Barham, B., 2015. Amish dedication to farming and adoption of organic dairy systems, in: Re-Thinking Organic Food and Farming in a Changing World. Springer, pp. 233-255.

Canal do Produtor, 2012. Seaf paga R 192 milhões (Seaf pays R 192 million). Noticias de Mercado.

Coquil, X., Beguin, P., Dedieu, B., 2014. Evolution towards mixed-crop organic dairy systems: reinforcement of crop/livestock interfaces. Economie Rurale 81-94.

Cortner, O., Garrett, R., Valentim, J., Ferreira, J., Niles, M, Reis, J., Gil, J., 2019. Perceptions of integrated crop-livestock systems for sustainable intensification in the Brazilian Amazon. Land Use Policy.

Cunfer, G., 2004. Manure matters on the Great Plains frontier. Journal of Interdisciplinary History 34, 539-567.

Dimitri, C., Effland, A.B., Conklin, N.C., others, 2005. The 20th century transformation of US agriculture and farm policy. US Department of Agriculture, Economic Research Service Washington, DC.

Dimitri, C., Greene, C., 2000. Recent growth patterns in the US organic foods market. Agriculture information bulletin 777.

Dowd, B.M., Press, D., Los Huertos, M., 2008. Agricultural nonpoint source water pollution policy: The case of California's Central Coast. Agriculture, ecosystems \& environment 128, 151-161.

Dumont, A.M., Vanloqueren, G., Stassart, P.M., Baret, P.V., 2016. Clarifying the socioeconomic dimensions of agroecology: Between principles and practices. Agroecology and Sustainable Food Systems 40, 24-47.

Dumont, B., Ryschawy, J., Duru, M., Benoit, M., Chatellier, V., Delaby, L., Donnars, C., Dupraz, P., Lemauviel-Lavenant, S., Méda, B., 2018. Associations among goods, impacts and ecosystem services provided by livestock farming. animal 1-12.

EIP-AGRI, 2017. Focus Group Mixed farming systems: livestock/cash crops. Bruxelles, Belgium.

Embrapa, 2016. Integração Lavoura Pecuária Floresta - ILPF (Integration Crop Livestock Forest). Brasilia. 
Evans, L., Grimes, A., Wilkinson, B., Teece, D., 1996. Economic Reform in New Zealand 1984-95: The Pursuit of Efficiency. Journal of Economic Literature 34, 1856-1902.

FAO, 2010. An international consultation on integrated crop-livestock systems for development: The Way Forward for Sustainable Production. Food and Agriculture Organization.

Farrin, K., Miranda, M.J., O’Donoghue, E., 2016. How Do Time and Money Affect Agricultural Insurance Uptake? A New Approach to Farm Risk Management Analysis (No. 262194), Economic Research Report. United States Department of Agriculture, Economic Research Service.

Faust, D.R., Kumar, S., Archer, D.W., Hendrickson, J.R., Kronberg, S.L., Liebig, M.A., 2017. Integrated Crop-Livestock Systems and Water Quality in the Northern Great Plains: Review of Current Practices and Future Research Needs. Journal of environmental quality.

Flores, M.X., 1991. EMBRAPA Project: agricultural research going into the XXI century. Brasilia.

Fonterra, 2015. Fonterra enhances reputation as world-leading dairy producer [WWW Document]. URL https://www.fonterra.com

Gaigne, C., 2012. Organisation of the livestock sector and the environment. 20 years after the nitrate directive. INRA PRODUCTIONS ANIMALES 25, 375-388.

Garrett, R.D., Gardner, T., Fonseca, T., Marchand, S., Barlow, J., de Blas, D.E., Ferreira, J., Lees, A.C., Parry, L., 2017a. Explaining the persistence of low income and environmentally degrading land uses in the Brazilian Amazon. Ecology and Society 22. https://doi.org/10.5751/ES-09364-220327

Garrett, R.D., Koh, I., Lambin, E.F., le Polain de Waroux, Y., Kastens, J.H., Brown, J.C., 2018. Intensification in agriculture-forest frontiers: Land use responses to development and conservation policies in Brazil. Global Environmental Change 53, 233-243. https://doi.org/10.1016/j.gloenvcha.2018.09.011

Garrett, R.D., Lambin, E.F., Naylor, R.L., 2013a. Land institutions and supply chain configurations as determinants of soybean planted area and yields in Brazil. Land Use Policy 31, 385-396.

Garrett, R.D., Lambin, E.F., Naylor, R.L., 2013b. The new economic geography of land use change: supply chain configurations and land use in the Brazilian Amazon. Land Use Policy 34, 265-275. https://doi.org/10.1016/j.landusepol.2013.03.011

Garrett, R.D., Niles, M., Gil, J.D.B., Dy, P., Reis, J., Valentim, J.F., 2017b. Policies for reintegrating crop and livestock systems: A comparative analysis. Sustainability 9, 473. https://doi.org/10.3390/su9030473

Gil, J.D.B., Garrett, R.D., Berger, T., 2016. Determinants of crop-livestock integration in Brazil: Evidence from the household and regional levels. Land Use Policy 59, 557-568.

Gwin, L., 2009. Scaling-up Sustainable Livestock Production: Innovation and Challenges for Grass-fed Beef in the U.S. Journal of Sustainable Agriculture 33, 189-209. https://doi.org/10.1080/10440040802660095

Hacker, R.B., Robertson, M.J., Price, R.J., Bowman, A.M., 2009. Evolution of mixed farming systems for the delivery of triple bottom line outcomes: a synthesis of the Grain \& Graze program. Animal Production Science 49, 966-974.

Hilimire, K., 2011. Integrated Crop/Livestock Agriculture in the United States: A Review. Journal of Sustainable Agriculture 35, $376-393$. https://doi.org/10.1080/10440046.2011.562042

IBGE, 2006. Agriculture and Livestock Census [WWW Document]. Brazilian Institute of Geography and Statistics. URL http://sidra.ibge.gov.br Key, N., 2005. How much do farmers value their independence? Agricultural Economics 33, 117-126. 
Kiem, A.S., 2013. Drought and water policy in Australia: Challenges for the future illustrated by the issues associated with water trading and climate change adaptation in the Murray-Darling Basin. Global Environmental Change 23, 1615-1626. https://doi.org/10.1016/j.gloenvcha.2013.09.006

Lacoste, M., Lawes, R., Ducourtieux, O., Flower, K., 2018. Assessing regional farming system diversity using a mixed methods typology: the value of comparative agriculture tested in broadacre Australia. Geoforum 90, 183-205. https://doi.org/10.1016/j.geoforum.2018.01.017

Lawrence, J.D., 2002. Quality Assurance" Down Under": Market Access and Product Differentiation.

Lemaire, G., Franzluebbers, A., 2013. Integrated crop-livestock systems: Strategies to achieve synergy between agricultural production and environmental quality. Agriculture, Ecosystems and Environment 190, 4-8. https://doi.org/10.1016/j.agee.2013.08.009

Lovell, S.T., Nathan, C.A., Olson, M.B., Mendez, V.E., Kominami, H.C., Erickson, D.L., Morris, K.S., Morris, W.B., 2010. Integrating agroecology and landscape multifunctionality in Vermont: An evolving framework to evaluate the design of agroecosystems. Agricultural Systems 103, 327-341.

Lubell, M., Niles, M., Hoffman, M., 2014. Extension 3.0: Managing Agricultural Knowledge Systems in the Network Age. Society \& Natural Resources 27, 1089-1103.

MacLeod, C.J., Moller, H., 2006. Intensification and diversification of New Zealand agriculture since 1960: An evaluation of current indicators of land use change. Agriculture, ecosystems \& environment 115, 201-218.

MBAgro, 2012. Seguro Agrícola no Brasil: Uma visão estratégica de sua importância para a economia Brasileira.

Ministry for Primary Industries, 2016. New Zealand food legislation.

Minneé, E.M.K., Fletcher, A.L., De Ruiter, J.M., Clark, D.A., 2009. Forage crop sequences for pastoral systems in northern New Zealand, in: Proceedings of the New Zealand Grassland Association. New Zealand Grassland Association, pp. 93-100.

Moraine, M., Duru, M., Therond, O., 2017. A social-ecological framework for analyzing and designing integrated crop-livestock systems from farm to territory levels. Renewable Agriculture and Food Systems 32, 43-56.

MPI, 2015. Sustainable Farming Fund.

New Zealand Government, 2015. Steps to importing [WWW Document]. URL https://www.mpi.govt.nz/importing/food-for-animals/ingredientsfor-animal-food/steps-to-importing/

New Zealand Ministry for Foreign Affairs and Trade (MFAT), 2012. Tariff Schedule of New Zealand. New Zealand Ministry for Foreign Affairs and Trade, Wellington, New Zealand.

NIFA, 2016. Programs.

NIFA, 2015. Agriculture and Food Research Initiative Competitive Grants Program: Food Security Program.

Niles, M., Garrett, R., Walsh, D., 2018. Ecological and economic benefits and challenges for integrating sheep into viticulture production. Agronomy for Sustainable Development 38.

NZAGRC, 2016. Integrated Systems.

Observatorio ABC, 2016. Analise dos recursos do Programa ABC - Visao Regiona. Fundacao Getulio Vargas, Sao Paulo.

O’Donoghue, E.J., Roberts, M.J., Key, N., 2009. Did the Federal Crop Insurance Reform Act Alter Farm Enterprise Diversification? Journal of Agricultural Economics 60, 80-104. https://doi.org/10.1111/j.1477-9552.2008.00166.x

Organisation for Economic Development (OECD), 2016. Agricultural Policy Monitoring and Evaluation. 
Pangborn, M.C., 2009. The Impact of the Lincoln University Dairy Farm and the South Island Dairying Development Centre on Canterbury and North Otago Farmers.

Parker, J.S., 2013. Integrating culture and community into environmental policy: community tradition and farm size in conservation decision making. Agric Hum Values 30, 159-178. https://doi.org/10.1007/s10460-012-9392-8

Parker, J.S., Moore, R., Weaver, M., 2009. Developing participatory models of watershed management in the Sugar Creek Watershed (Ohio, USA). Water Alternatives 2, 82.

Peyraud, J.-L., Taboada, M., Delaby, L., 2014. Integrated crop and livestock systems in Western Europe and South America: A review. European Journal of Agronomy. https://doi.org/10.1016/j.eja.2014.02.005

Pigford, A.-A.E., Hickey, G.M., Klerkx, L., 2018. Beyond agricultural innovation systems? Exploring an agricultural innovation ecosystems approach for niche design and development in sustainability transitions. Agricultural Systems 164, 116-121.

Ploeg, J.D. van der, 2010. The peasantries of the twenty-first century: the commoditisation debate revisited. The Journal of Peasant Studies 37, 130. https://doi.org/10.1080/03066150903498721

Price, R.J., 2009. Research management, institutional arrangements and the quest for integration in mixed-farming innovation: the emergence of point-of-practice integration. Animal Production Science 49, 928-940.

Price, R.J., Hacker, R.B., 2009. Grain \& Graze: an innovative triple bottom line approach to collaborative and multidisciplinary mixed-farming systems research, development and extension. Animal Production Science 49, 729-735.

Productivity Commission, 2005. Trends in Australian Agriculture (No. 0502), Research Papers. Productivity Commission, Government of Australia.

Prokopy, L.S., Floress, K., Klotthor-Weinkauf, D., Baumgart-Getz, A., 2008. Determinants of agricultural best management practice adoption: Evidence from the literature. Journal of Soil and Water Conservation 63, 300-311.

Ryschawy, J., Choisis, N., Choisis, J.P., Gibon, A., 2013. Paths to last in mixed crop-livestock farming: lessons from an assessment of farm trajectories of change. Animal : an international journal of animal bioscience 7, 673-81. https://doi.org/10.1017/S1751731112002091

Ryschawy, J., Garrett, R.D., Gaudin, A., Niles, M.T., Tiffany, S., In Review. Farmers' perceptions of sheep-viticulture integration systems. A case-study in California.

Ryschawy, J., Martin, G., Moraine, M., Duru, M., Therond, O., 2017. Designing crop-livestock integration at different levels: Toward new agroecological models? Nutrient Cycling in Agroecosystems 1-16.

Salay, E., Caswell, J.A., 1998. Developments in Brazilian food safety policy. The International Food and Agribusiness Management Review 1, $167-177$.

Schiere, J.B., Ibrahim, M.N.M., Van Keulen, H., 2002. The role of livestock for sustainability in mixed farming: criteria and scenario studies under varying resource allocation. Agriculture, ecosystems \& environment 90, 139-153.

Stinner, D.H., Paoletti, M.G., Stinner, B.R., 1989. In search of traditional farm wisdom for a more sustainable agriculture: a study of Amish farming and society. Agricultural Ecology and Environment 77-90.

Stock, P.V., Forney, J., 2014. Farmer autonomy and the farming self. Journal of Rural Studies 36, 160-171.

Sulc, R.M., Tracy, B.F., 2007. Integrated Crop-Livestock Systems in the U.S. Corn Belt. Agronomy Journal 99, 335-345.

Sullivan, S., Mccann, E., De Young, R., Erickson, D., 1996. Farmers' attitudes about farming and the environment: A survey of conventional and organic farmers. Journal of Agricultural and Environmental Ethics 9, 123-143. https://doi.org/10.1007/BF03055298 
USDA, 2015. USDA NIFA Integrated Research, Education, and Extension Competitive Grants Program - Organic Transitions.

USDA, 2013. About the risk management agency, A Risk Management Agency Fact Sheet.

Veysset, P., Bébin, D., Lherm, M., 2005. Adaptation to Agenda 2000 (CAP reform) and optimisation of the farming system of French suckler cattle farms in the Charolais area: a model-based study. Agricultural Systems 83, 179-202.

Waters, W., Thomson, D., Nettle, R., 2009. Derived Attitudinal Farmer Segments: A Method for Understanding and Working with the Diversity of Australian Dairy Farmers. Extension Farming Systems Journal 5, 47.

Zilberman, D., Templeton, S.R., Khanna, M., 1999. Agriculture and the environment: an economic perspective with implications for nutrition. Food policy 24, 211-229. https://doi.org/10.1016/S0306-9192(99)00026-3 